\title{
Recuperação ambiental ou recuperação de áreas degradadas: conceitos e procedimentos
}

\author{
Maurício Novaes Souza
}

https://doi.org/10.4322/mp.978-65-991393-6-9.c1

\section{Introdução}

Atualmente, existe a opinião nos meios científico, empresarial e na sociedade, advertindo que o Planeta está caminhando a um desastre ecológico sem precedentes. Tais opiniões procedem, quando considerado o desarranjo volumoso nos sistemas naturais da Terra, dos quais a nossa civilização depende. Entretanto, há uma percepção difusa por parte da sociedade que, complacentemente, afirma que a situação não é tão drástica, inclusive afirmando e opinando, que o atual momento mundial é o melhor de todos os tempos. Ainda, existe um menor, mas crescente coro discutindo que ambas estas percepções são verdadeiras, pelo menos em parte (SCHLEV e LAUR, 1998; SOUZA, 2018).

Uma maneira para conciliar estes contraditórios pontos de vista, consiste em perceber que está se vivendo em um tempo de grandes oportunidades, com a chance de construir um novo caminho para a busca do desenvolvimento sustentável. Porém, deverá ser significativamente diferente do aparecimento da indústria e da agropecuária nos séculos XIX e XX. Para construir o caminho nessa direção, exigirá maior conhecimento por parte dos indivíduos, organizações, empresas e da sociedade em geral.

Os conhecimentos atuais ainda são tênues em relação à necessidade de se desenvolver uma nova ordem, para sobreviver e prosperar no século XXI. As notícias ruins são que os problemas com os biomas e os diversos ecossistemas terrestres, tanto hoje como no futuro, são enormes. O espírito empreendedor humano realmente desenvolveu um risco considerável para o planeta. As boas notícias são que as oportunidades atuais são imensamente maiores. Para desenvolvê-las e colhê-las, precisa-se propor mudanças importantes nos modelos de educação, de produção e de gestão (SCHLEV e LAUR, 1998; SOUZA, 2018).

De acordo com CASTELLS (1999), as grandes empresas passaram a incluir as questões ambientais como um componente rotineiro do seu negócio. Porém, adverte: a maioria dos problemas ambientais persiste, posto que seu tratamento requeira uma transformação nos meios de produção e de consumo, bem como de nossa organização social e de nossas vidas pessoais.

Para BERNARDES e FERREIRA (2003), vale ressaltar alguns eventos internacionais que envolvem a política ambiental e a tomada de consciência sobre a importância deste assunto em nível global. O desastre ocorrido na Baía de Minamata, no Japão, detonou a solicitação sueca para uma reunião mundial com vistas ao modelo de 
desenvolvimento e às questões ambientais. Foi realizada em Estocolmo, em 1972, a Conferência das Nações Unidas sobre o Meio Ambiente, que teve como ponto marcante a contestação às propostas do Clube de Roma sobre o crescimento zero para os países em desenvolvimento.

Porém, de acordo com esses mesmos autores, ficou reconhecido por toda a comunidade internacional, em função de comprovações científicas, a vinculação entre desenvolvimento e meio ambiente, sendo aceita a consideração que é responsabilidade majoritária dos países desenvolvidos a contaminação do planeta.

Foram criados programas e comissões importantes tais como o Programa das Nações Unidas para o Meio Ambiente (PNUMA) e a Comissão Mundial sobre o Meio Ambiente e o Desenvolvimento (CMMAD), estabelecendo o assunto definitivamente na agenda e nas discussões da ONU.

A mais importante reunião, depois de Estocolmo, foi a Conferência de Meio Ambiente e Desenvolvimento (ECO 92), que promoveu definitivamente a internacionalização da proteção ambiental e das questões ligadas ao desenvolvimento, como também a necessidade de recuperação de áreas degradadas.

Dessa forma, em vista de novos níveis de prosperidade - que podem ser sustentados quando são observados os aspectos econômicos, ecológicos e sociais - conquista-se crescentemente maior número de pessoas em seu serviço. Entretanto, para atingir tais objetivos, faz-se necessário:

a) assumir novas estratégias; b) estabelecer compromissos mais fortes; e c) investir em trabalhos que evidentemente são difíceis, como intensificar as pesquisas para aprender mais sobre recuperação ambiental.

Percebem-se, ao longo dos últimos trinta anos, nos países desenvolvidos e no Brasil, que a qualidade e quantidade de áreas degradadas recuperadas têm sido significativamente aperfeiçoadas. A sociedade expressa sua determinação exigindo e fiscalizando o fim de práticas industriais e de uso do solo e da água que causem degradação ambiental em longo prazo, por meio de numerosos regulamentos federais, estaduais e locais.

A indústria, aos poucos, vem aceitando a responsabilidade para a mitigação dos impactos negativos e a recuperar danos causados aos sistemas ambientais. Resultados bem sucedidos de recuperação estão sendo divulgados mensalmente em jornais, periódicos, TV e "internet". Infelizmente, algumas concepções erradas ainda persistem, relativas aos abusos ambientais praticados por alguns setores das atividades produtivas, baseadas em hábitos do passado (TOY e DANIELS, 1998; TOY; FOSTER; RENARD, 2002; GRIFFITH, 2002; SOUZA, 2018).

Além das exigências legais, da cobrança da sociedade civil organizada e do acúmulo de pesquisas e resultados de experiências, a melhoria dos procedimentos de recuperação pode ser responsabilizada por avanços em (MEYER e RENARD, 1991; TOY e DANIELS, 1998; TOY; FOSTER; RENARD, 2002; SOUZA, 2015; 2018):

De acordo com esses mesmos autores, a avaliação de impactos ambientais e o planejamento da recuperação têm beneficiado a expansão de bancos de dados e refinamentos de modelos hidrológicos, geomórficos e de engenharia. A evolução da computação facilitou a eficiência destes modelos e a acessibilidade a banco de dados. 
Emergiu um mercado para equipamento especializado, com o fato de o tema recuperação ter-se tornado operação padrão nos negócios rotineiros de várias indústrias.

A inovação de produtos, como os "drones", ou aqueles voltados para o controle de erosão, por exemplo, eram desenvolvidos exclusivamente para circunstâncias especiais. Também, a variedade e quantidade de sementes disponíveis para revegetação aumentaram, especialmente para espécies nativas. A partir da crescente mobilização mundial por um novo modelo de desenvolvimento, fez com que as novas políticas ambientais trouxessem um significativo apoio às pesquisas na área de recuperação ambiental.

Atualmente, vários grupos têm contribuído nesse sentido, em nível internacional, tais como: a) as seguradoras, em função dos crescentes prejuízos financeiros decorrentes de alterações climáticas em todo o mundo, têm funcionado como um forte aliado exercendo o papel de um grupo de interesse voltado para os procedimentos de recuperação; b) organismos internacionais, como a Organização das Nações Unidas (ONU), o Banco Mundial (BIRD) e o Banco Interamericano de Desenvolvimento (BID), além de funcionarem como agentes econômicos e de política burocrática, vêm funcionando, também, como grupos de interesse em pesquisa; nesse caso, de forma construtivista; e c) as Organizações Não-Governamentais (ONGs).

Porém, para que ocorra o sucesso da recuperação ambiental de forma eficiente e duradoura, esta não pode ser assumida como um fato isolado, valendo-se de soluções bem-intencionadas, mas que na verdade visem auferir lucro ou apenas resposta imediata para atender o desejo do empreendedor e satisfazerem às exigências do órgão ambiental fiscalizador.

De acordo com Nardelli e Nascimento (2000); Griffith (2000); e Souza (2018), o pensamento sistêmico, teoria que mostra um novo tipo de pensar e de relações que se interagem e integram-se, mostra que a adoção de soluções sintomáticas gera outros efeitos adversos não considerados anteriormente. Dessa forma, observa-se que o processo de recuperação ambiental é complexo, exigindo tempo, recursos e conhecimento dos diversos fatores que compõem ou podem interferir na área a ser recuperada.

Para devem ser incluídos os diversos atores sociais afetados ou envolvidos na área direta e indiretamente afetada, considerando seus valores e interesses. Assim, a etapa inicial do planejamento do projeto de recuperação ambiental, permitirá que seja conhecida a amplitude do problema ambiental para o qual este projeto será destinado. Neste ponto, deverá ser traçado o plano de recuperação com os objetivos de médio e longo prazo, bem definido e coerente com a realidade.

Devem-se considerar o objetivo, a abrangência, as externalidades e a totalidade das relações físicas, biológicas, políticas, socioeconômicas, tecnológicas e culturais da área na qual o projeto está ou será inserido.

\section{Objetivos}

O objetivo desse capítulo é analisar o início dos procedimentos de recuperação ambiental no Brasil e a sua evolução até aos dias atuais. Dessa forma, pretende-se justificar a sua necessidade e os principais passos que deverão ser observados para o seu sucesso e a sua autossustentabilidade. 
Objetiva também:

- Conhecer metodologias para a identificação dos estádios de degradação e ferramentas para o seu diagnóstico e monitoramento;

- Verificar a interligação e a interdependência entre os recursos naturais e os aspectos socioeconômicos nos procedimentos de recuperação;

- Identificar a importância de alguns procedimentos, como o estabelecimento de cenários pré e pós-degradação, para a sustentabilidade da recuperação; e

- Visualizar a importância da interdisciplinaridade nas pesquisas relacionadas à recuperação ambiental.

\section{Definições e objetivos}

O Ministério do Meio Ambiente, por meio da Instrução Normativa $n^{\circ} 5 / 2009$, define área degradada como uma área onde a vegetação, flora, fauna e, ou, solo foram total ou parcialmente destruídos, removidos e expulsos, tendo alterados sua capacidade produtiva e qualitativa (MMA, 2009).

Outros autores definem área degradada ou ecossistema degradado, como aquele que, após distúrbio, teve: a) eliminados juntamente com a vegetação nativa, os seus meios de regeneração biótica como banco de sementes, banco de plântulas, chuva de sementes e órgãos ou partes que possibilitem a rebrota, inclusive com a perda da camada fértil do solo; b) a fauna destruída, removida ou expulsa; e c) a qualidade e regime de vazão do sistema hídrico alterados (CARPANEZZI et al., 1990; IBAMA, 1990; SOUZA, 2018).

De acordo com SOUZA (2018), o surgimento de áreas degradadas no Brasil tem aumentado ao longo dos anos, ocasionando inúmeros impactos e danos ao meio ambiente, estando na maioria das vezes relacionado às atividades antrópicas sem planejamento. A degradação, na maioria das vezes, caracteriza-se pela remoção do horizonte superficial do solo, promovendo a perda das propriedades edáficas, favorecendo a atuação de processos erosivos: principal causa de degradação dos solos.

Tavares et al. (2008) citam que a erosão, de acordo com as atividades causadoras, pode ser classificada em geológica e antrópica. A erosão geológica tem como causa as atividades geológicas naturais, originadas pela água, ar, vento e gelo sobre a superfície terrestre, sem interferência humana. Já a erosão antrópica, refere-se aos resultados da interferência antrópica sobre o ambiente, intensificando-se quando associada à erosão geológica.

Em função de uma dada área apresentar pouco ou nenhum remanescente de vegetação, associados à interferência antrópica, poderá culminar em uma área de risco, onde não seria possível a regeneração natural. Nessas condições, terá sua resistência reduzida, a resiliência prejudicada, ocorrendo a degradação ambiental devido à perda de adaptação às características físicas, químicas e biológicas.

Nesse caso, ocorre a necessidade inicial de se realizar a recuperação física para posterior revegetação e regeneração biológica. A recuperação física compreende o preparo da superfície degradada, por meio da aplicação de tratamentos e técnicas que visam o controle de processos erosivos e o posterior estabelecimento de cobertura vegetal.

Nessas situações, o retorno desta área ao estado anterior pode não ocorrer ou ser extremamente lento, produzindo continuamente impactos ambientais negativos, 
tornando necessária a ação antrópica para a recuperação desses ecossistemas e possibilitar o restabelecimento do desenvolvimento socioeconômico (Figura 1).

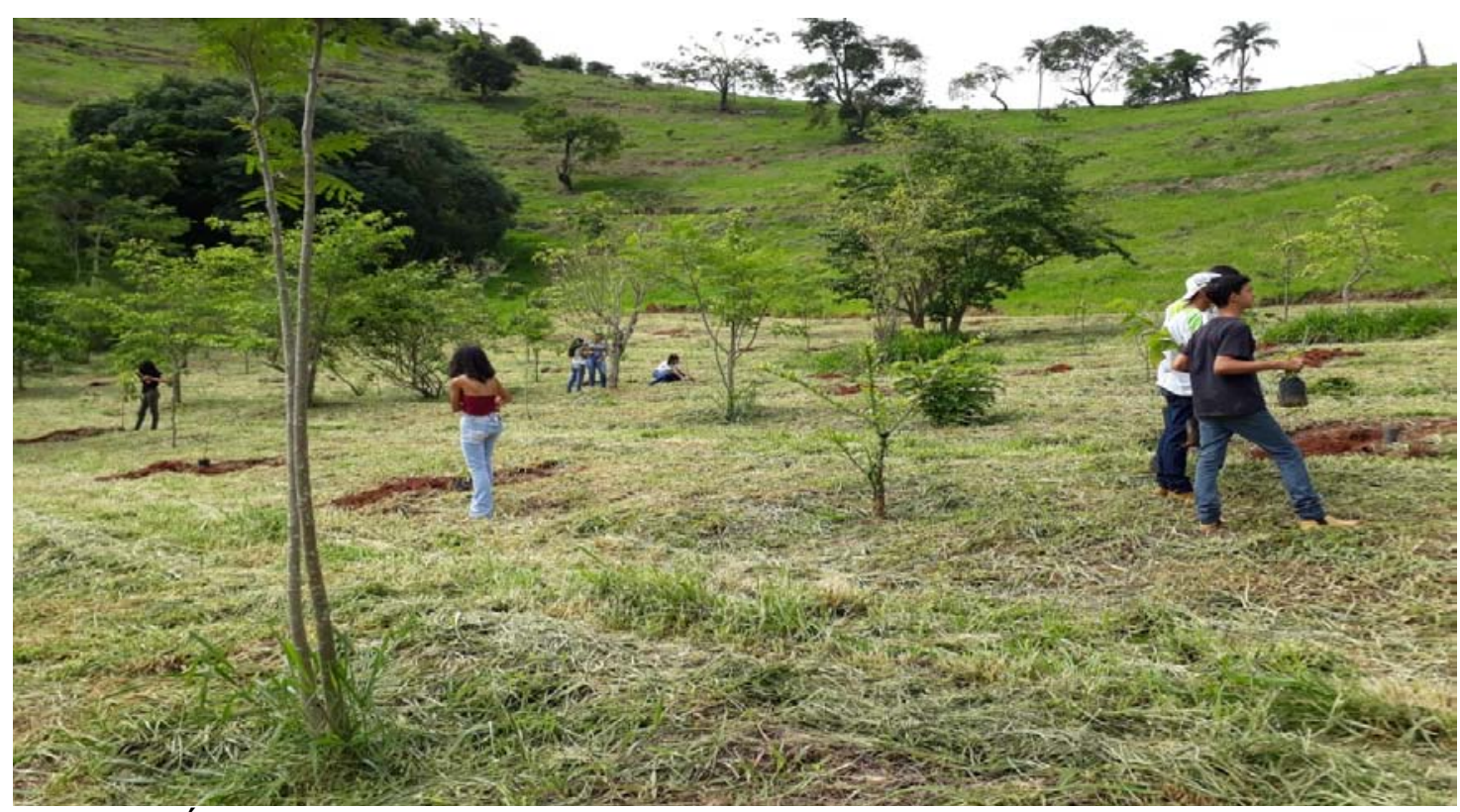

Figura 1. Área de APP no IF Sudeste de Minas campus Rio Pomba em fase final de recuperação: roçada e replantio de mudas.

Já "Ecossistema perturbado" ou "alterado", é aquele que sofreu distúrbio, mas manteve meios de regeneração biótica. A ação humana não é obrigatória, sendo necessário somente auxiliar na recuperação desse ambiente, pois a natureza pode se encarregar da tarefa (Figuras 2 e 3). Em ecossistemas degradados, a ação antrópica para a recuperação quase sempre é necessária.
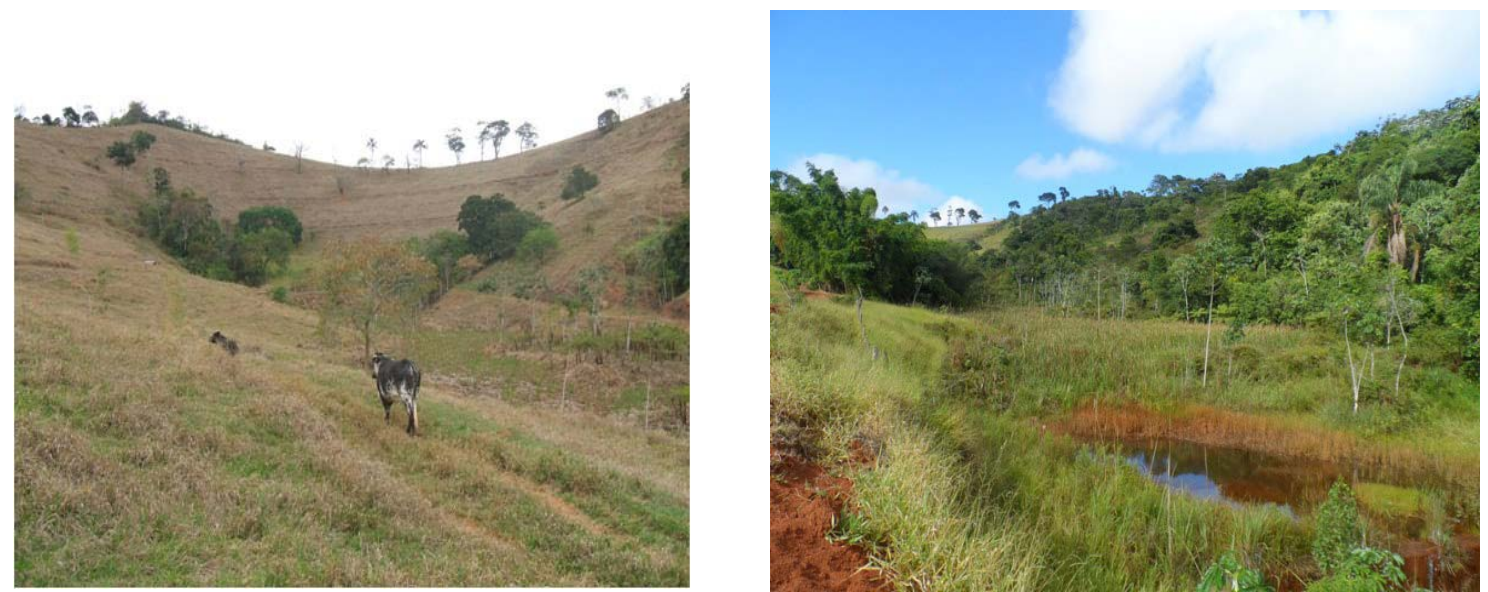

Figuras 2 e 3. Área perturbada de APP no IF Sudeste de Minas campus Rio Pomba (2004) e recuperada por isolamento e regeneração natural em estádio avançado de sucessão (2011).

Considerando que esses sistemas possuem energia armazenada, pode-se considerar que o ambiente degradado apresenta a perda dessa energia (Figura 2). BLUM (1998) identifica e sugere três tipos de energia envolvidos nesses compartimentos:

- Gravitacional: é a energia que controla a maior parte de movimentos dos sólidos, líquidos e gases, sendo determinante para alguns fenômenos, tais como erosão e sedimentação; 
- Conservada: é a energia existente e presente no material de origem, sendo proveniente das forças internas da Terra, tais como pressão e temperatura; e

- Solar: é a energia de maior importância para o crescimento e desenvolvimento das espécies vegetais. Por meio do processo de fotossíntese, os vegetais transformam o gás carbônico atmosférico em componentes orgânicos que são transferidos ao solo.

Considerando-se esse conceito, no qual as funções e uso do solo têm como base a sua energia armazenada, implica em dizer, que degradação do solo significa a perda de suas funções e usos. Dessa forma, a degradação ambiental pode ser definida nas formas específicas de energia. Assim, todas as atitudes a serem definidas na recuperação ou no uso de áreas degradadas, devem considerar o nível de energia no sistema (KOBIYAMA; MINELLA; FABRIS, 2001).

Observa-se, entretanto, na maioria dos conceitos relacionados à área degradada, a priorização em relacioná-la ao fator solo ou terra. Isso porque o solo é um componente essencial para a manutenção da sustentabilidade dos ecossistemas, necessitando de um equilíbrio quanto suas características físicas, químicas, biológicas e, inclusive, em seus aspectos visuais, sendo que a degradação dos solos se constitui como grave prejuízo socioeconômico para as gerações atuais e futuras (CÂNDIDO FILHO et al., 2015).

Sabe-se, porém, que a degradação engloba não apenas o solo, mas também a água, o ar e os organismos. Sob esta visão, KOBIYAMA; USHIWATA; BARCIK (1993) definiram degradação, como "processos e fenômenos do meio ambiente, naturais ou antropogênicos ${ }^{1}$, que prejudicam as atividades de um ou mais organismos".

A partir dessa definição, esses mesmos autores conceituaram área degradada considerando a sua entropia (S), que pode ser definida como a divisão entre calor (Q) e temperatura $(\mathrm{T})$, ou seja:

$$
\mathrm{dS}=\mathrm{dQ} / \mathrm{T}
$$

Entendem, assim, que "entropia" representa a "sujeira" no sistema, resultando na desarmonia dos processos envolvidos. Dentro dessa visão, área degradada é aquela que apresenta maior entropia do que um ambiente equilibrado.

Para ODUM (1988), entropia é a medida da energia não disponível que resulta das transformações, como nos processos de dispersão, havendo queda de qualidade, posto não ocorrer tais processos, mesmo espontâneos, sem a ocorrência de perdas. Então, quanto menor a entropia (relação percentual entre a energia dissipada sem aproveitamento e a total utilizada), maior é a eficiência do processo de transformação.

Tratando-se da recuperação propriamente dita, é comum a citação de termos como recuperação, reabilitação e restauração como se fosse um único processo. TOY e DANIELS (1998) definem três categorias de tratamento de recuperação de solo:

- Reabilitação: o solo é retornado à forma e produtividade em conformidade com a sua capacidade de uso, incluindo sua estabilidade e equilíbrio ecológico, que

\footnotetext{
${ }^{1}$ NOTA: No sentido de «relativo à ação do homem sobre o ambiente» (dicionário da Porto Editora), recomenda-se antrópico (como em «processos antrópicos»; cf. dicionário da Priberam). Embora antropogênico seja empregado frequentemente com o mesmo significado, a sua constituição remete para antropogênese, «estudo da origem e do desenvolvimento da espécie humana, especialmente como objeto de investigação científica» (Dicionário Houaiss), e, portanto, deve ser reservado para fazer referência a este tipo de estudo.
} 
não contribua substancialmente para a deterioração ambiental e com os valores estéticos circundantes;

- Recuperação: o local é novamente hospitaleiro para organismos que eram originalmente presentes ou outros que se aproximam das populações originais; e

- Restauração: a condição do local no momento da perturbação é reproduzida depois da ação.

Estes mesmos autores comentam que os termos reabilitação, recuperação e restauração não foram de maneira uniforme usado, sendo que outras denominações variaram ao longo dos anos. As leis e regulamentos pertinentes foram interpretados e cumpridos de diferentes modos, variando de acordo com o tempo e com o lugar. Atualmente, o termo "recuperação" é o que vem sendo mais utilizado no Brasil, mas com o entendimento que possibilidades alternativas de usos do solo, devem permanecer.

De acordo com Griffith et al. (2000),

\begin{abstract}
"a recuperação de áreas degradadas (RAD), ou recuperação ambiental (RA), é um conjunto de ações planejadas e executadas por especialistas de diferentes áreas do conhecimento humano, que visam proporcionar o restabelecimento da autossustentabilidade e do equilíbrio paisagístico semelhante aos anteriormente existentes, em um sistema natural que perdeu essas características. As pesquisas em recuperação ambiental têm enfocado tanto os problemas decorrentes das atividades agropecuárias, florestais, minerárias, construção civil, urbanização e industrialização, como aqueles decorrentes de processos naturais, tais como: enchentes, incêndios, secas, dilúvios e atividades sísmicas".
\end{abstract}

Neste capítulo, define-se recuperação ambiental como o tratamento de áreas alteradas/perturbadas para criar pedopaisagens estáveis e condições edáficas para se sustentarem, mediante uso do solo em sua condição predeterminante, exigindo condições mínimas de manutenção. Além disso, as comunidades existentes no local recuperado deverão conviver com essa nova paisagem em harmonia, dentro de uma nova realidade socioeconômica, onde haja maior equidade social: ou seja, propõe-se a recuperação socioambiental, que garantirá, de fato, a autossustentabilidade do ambiente.

\title{
4. Abordagens para a caracterização de área degradada
}

A degradação atinge o meio físico, biótico e antrópico. O solo, pela sua importância nos processos produtivos, talvez seja, entre todos os compartimentos, o mais investigado.

Apesar disso, caracterizá-lo num processo inicial de degradação, não é tarefa de fácil visualização. Solos agrícolas ou de pastagens, podem estar sofrendo erosão laminar, com remoção de camadas delgadas de solo dos horizontes superficiais $(O+A)$ onde estão concentrados os teores mais altos de matéria orgânica, micro e mesofauna do solo, além dos nutrientes minerais; contudo, sem apresentar significativa perda de produtividade, posto que esta diminua progressivamente, não permitindo, muitas vezes, efeitos visuais perceptíveis. 
Considerando a possibilidade de esse processo ocorrer em ambientes montanhosos, de elevada declividade e, ou, em grandes lançantes, poderá reduzir a cobertura do solo a uma mera camada superficial. Caso esse processo não seja interrompido por constantes intervenções, poderá evoluir para erosão em sulcos, ravina e, finalmente, voçorocas de grandes dimensões, com frequentes desmoronamentos e de difícil recuperação, particularmente onde o material é muito friável (Figura 4).

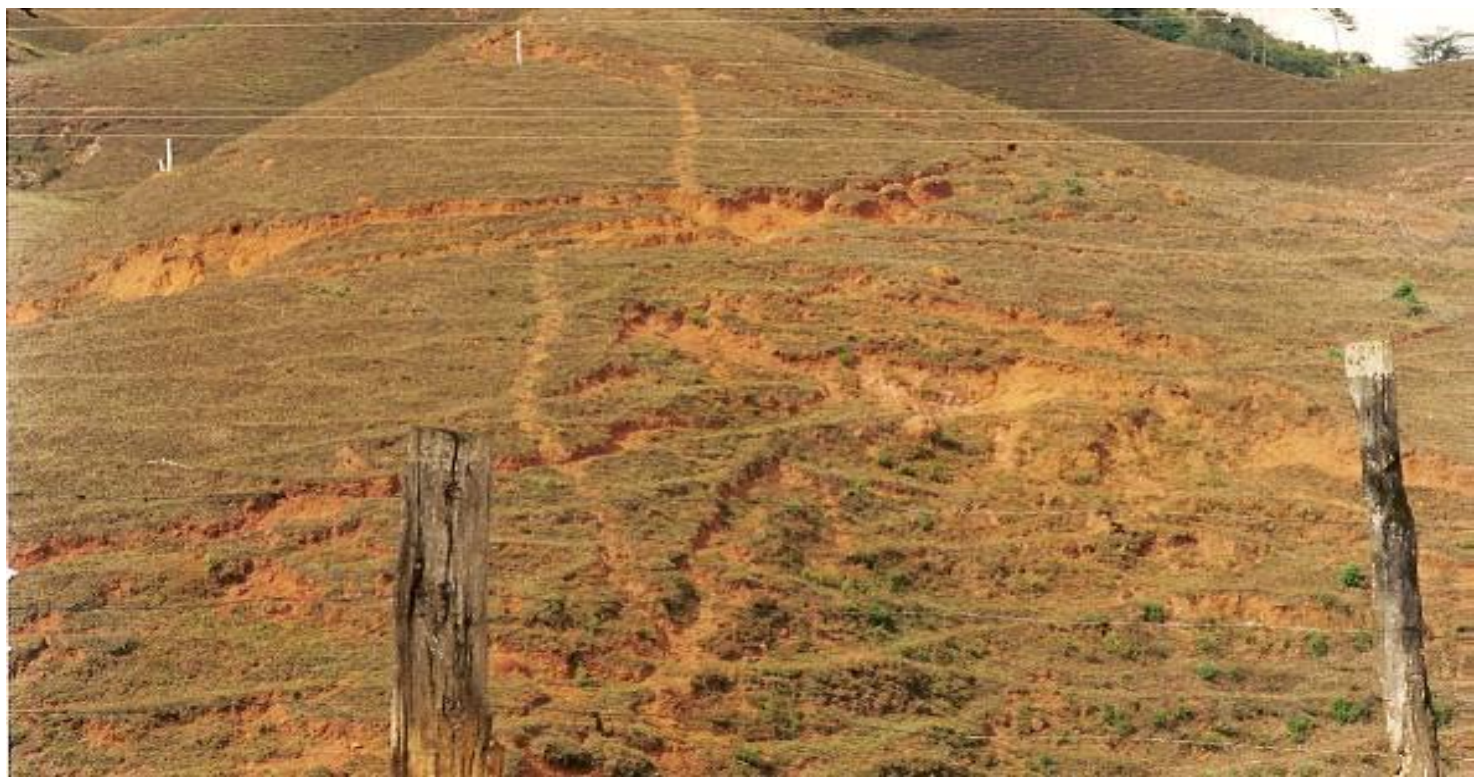

Figura 4. Área de pastagens em avançado estádio de degradação.

Para promover a compreensão desse processo, a ciência do solo tem procurado associar características peculiares de qualidade do solo, de tal forma que a partir do momento que surjam alterações, seja caracterizado o estádio de sua degradação. Porém, uma das dificuldades, é estabelecer quais são essas características e o padrão de referência, para que se possa definir e quantificar a qualidade do solo, para então proceder a sua caracterização (BERTONI; LOMBARDI NETO, 1990; IBAMA, 1990; DIAS; GRIFFITH, 1998; SOUZA, 2018).

Inicialmente, deve-se considerar a destinação pretendida a um determinado solo, para que se possa inferir sobre sua qualidade, posto que exigências e requerimentos, por exemplo, para agricultura ou para a construção civil, são diferenciados.

Dessa forma, solos que apresentam alta densidade podem apresentar como característica a compactação, que é favorável às edificações, porém indevida para práticas agropecuárias. Logo, observa-se relatividade no conceito de qualidade do solo (DIAS, 2003a).

Por este motivo, a caracterização de diferentes componentes de um sistema degradado requer a realização de análises físicas, químicas e biológicas, as quais exigem cuidados e procedimentos específicos, que devem ser considerados em função de variações qualitativas e quantitativas destes componentes (ibidem).

Sabe-se que as causas que originam fontes de degradação são diversas, tais como desflorestamento para abertura de novas fronteiras agropecuárias, uso inadequado do solo, mineração, despejo inadequado de resíduos ou mudanças socioeconômicas, na 
maioria das vezes, promovendo alta incidência de impactos ambientais negativos. Em quase todos os casos, ocorre a mudança do uso do solo, sem os devidos cuidados que se fariam necessários.

GRIFFITH (2001) considera que os processos que envolvem o restabelecimento destas áreas degradadas, baseiam-se na intervenção de componentes do ambiente, tais como os substratos, a vegetação e a fauna, corrigindo ou acrescentando aqueles que foram identificados a partir de um amplo estudo de caracterização da área.

A etapa inicial do planejamento deve permitir o conhecimento da amplitude do problema ambiental no qual o projeto de recuperação está inserido.

Assim, o ambiente degradado permite diferentes abordagens para a sua caracterização (DIAS, 2003a):

\section{a) Abordagem restritiva ou segmentada:}

Analisa-se cada componente (solo, água, ar), facilitando a visualização e a sua quantificação; e

b) Abordagem ampla ou não segmentada:

A partir de conceitos de ecologia, visualizando o ambiente como um conjunto de componentes que se encontra em equilíbrio ou, para Coelho (2001), em estado de relativa estabilidade, posto ser temporal, onde a energia erosiva permanece relativamente estabilizada.

\subsection{Abordagem segmentada}

Baseia-se na quantificação de indicadores de qualidade dos diversos compartimentos do ambiente. Um sistema é formado por inúmeros componentes em cada um dos compartimentos ambientais, que em situação de equilíbrio, realizam trocas necessárias para a sua manutenção, tais como gases, água e nutrientes (Figura 5).

Na visão segmentada, cada uma das variáveis desses componentes deve ser tomada e referenciada a padrões que permitam caracterizá-los qualitativamente (DIAS; GRIFFITH, 1998; DIAS, 2003a).

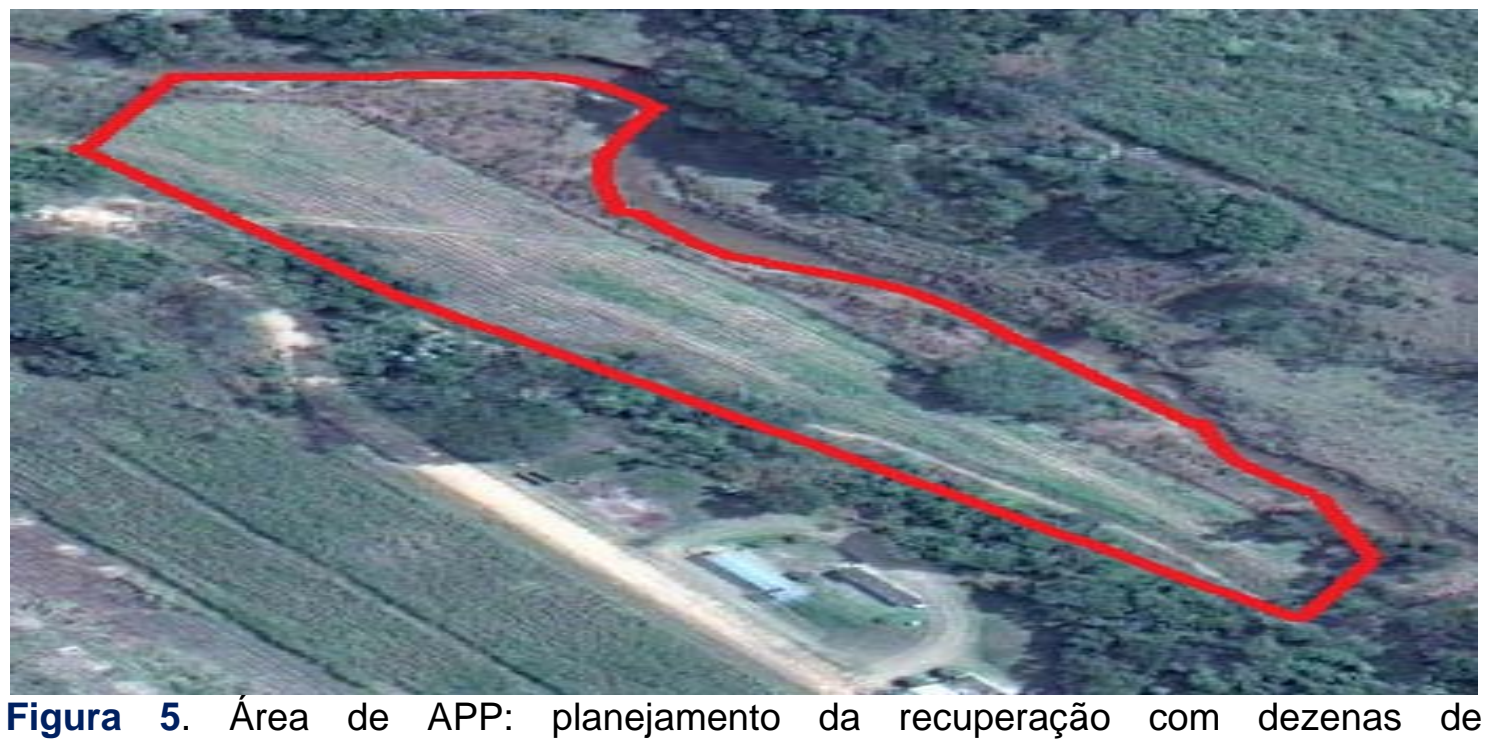
compartimentos ambientais. 


\subsubsection{Caracterização segmentada de área degradada: componente solo}

Solos são corpos naturais não consolidados na superfície da terra, organizados com características próprias adquiridas por meio da ação dos "fatores" e "processos" de formação sobre as rochas existentes na camada superficial da crosta terrestre, que evoluem durante os estágios de gênese e maturação. Tridimensionais, são constituídos por partes sólidas, líquidas e gasosas, possuindo intenso dinamismo em sua composição mineral e orgânica, em equilíbrio com o seu desenvolvimento, contendo matéria viva que dá suporte à vida animal, vegetal e outras atividades biológicas, num ambiente natural (VIEIRA, 1975; VIEIRA; SANTOS; VIEIRA, 1988; LIMA, 2002; RESENDE et al., 2002; SOUZA, 2004; 2018).

RESENDE et al. (2002) relatam as vantagens em aprender sempre mais a respeito do solo, posto que ele ocupa uma posição peculiar ligada às várias esferas que afetam a vida humana.

\section{É, além disso, o substrato principal da produção de alimentos e uma das principais fontes de nutrientes e sedimentos que vão para os rios, lagos e mares.}

Existe uma quantidade significativa de conhecimentos e generalizações a respeito de solos e seu comportamento; contudo, quando integrados no quadro socioeconômico, está longe de serem sistematizados, fazendo-se necessária muita pesquisa e observações no sentido de melhor entendê-lo.

Para conhecer os solos, é necessário fazer levantamentos, nos quais serão reconhecidos seus atributos morfológicos, físicos, químicos e mineralógicos (Figura 6).

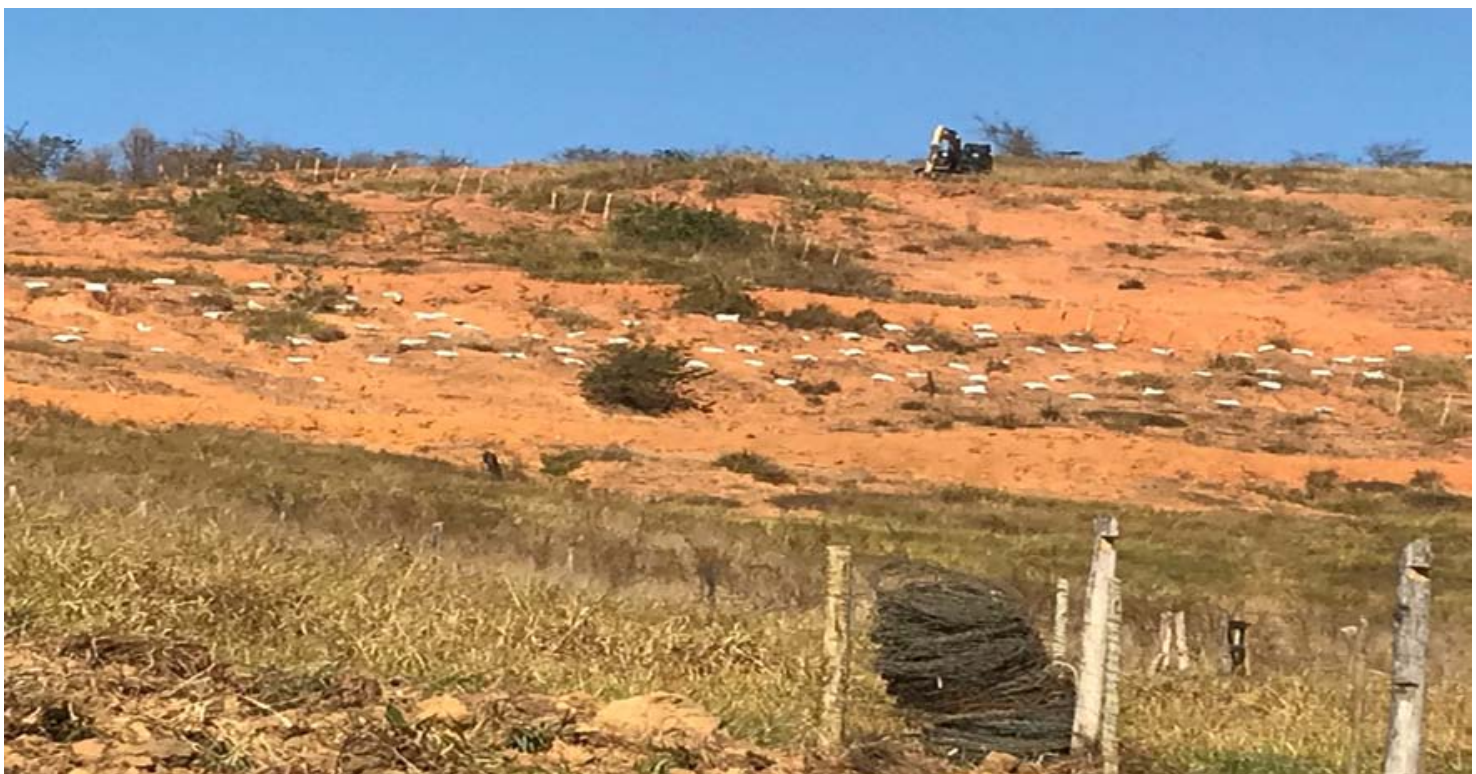

Figura 6. Área degradada sendo preparada para procedimentos de recuperação.

O levantamento inclui a classificação dos solos, que irá estabelecer e situar diferenças entre unidades, correlacionar e prever a adaptabilidade dos solos para diversas espécies florestais, seu comportamento e produtividade sob diferentes sistemas de manejo e as colheitas das espécies adaptadas sob conjuntos de práticas de manejo (CASTRO FILHO e MUZILLI, 2002). 
Essas informações são de extrema importância, fornecendo uma base geral para facilitar a compreensão de alguns fenômenos de fácil percepção no campo (como a relação clima, solo e biota) e estimular novas observações que facilitarão as tomadas de decisões nos processos de recuperação ambiental.

O solo é constituído de compostos sólidos provindos das rochas e da matéria orgânica, de líquidos e de gases. A presença desse material orgânico possibilita que as partículas sólidas mais finas, resultado final da ação do intemperismo sobre a rocha, possam formar agregados que se estruturam em uma forma definida, inclusive formando horizontes distintos ao longo do perfil.

Essa estrutura, que possui esses espaços vazios, denominados poros (macro e microporos), tem a capacidade de armazenamento de líquidos e gases. Quanto maior for o equilíbrio entre essas três fases, propiciarão maior atividade biológica e 0 estabelecimento do processo de ciclagem biogeoquímica, favorecendo 0 estabelecimento e o desenvolvimento da vegetação (VIEIRA; SANTOS; VIEIRA, 1988).

As proporções destas partículas (Quadro 1 e Figura 7), determinam a textura do solo. $\mathrm{O}$ arranjo das diversas partículas juntamente com os efeitos cimentantes de materiais orgânicos e inorgânicos, determinam a estrutura do solo.

Quadro 1. Tamanho das partículas do solo.

\begin{tabular}{|c|c|c|c|}
\hline Partículas & Diâmetro (mm) & Partículas & Diâmetro (mm) \\
\hline Matacões & $>200$ & Areia fina & $0,20-0,05$ \\
\hline Calhaus & $200-20$ & Silte & $0,05-0,002$ \\
\hline Cascalhos & $20-2$ & Argila & $<0,002$ \\
\hline Areia grossa & $2-0,20$ & & \\
\hline
\end{tabular}

Fonte: RESENDE et al., 2002.

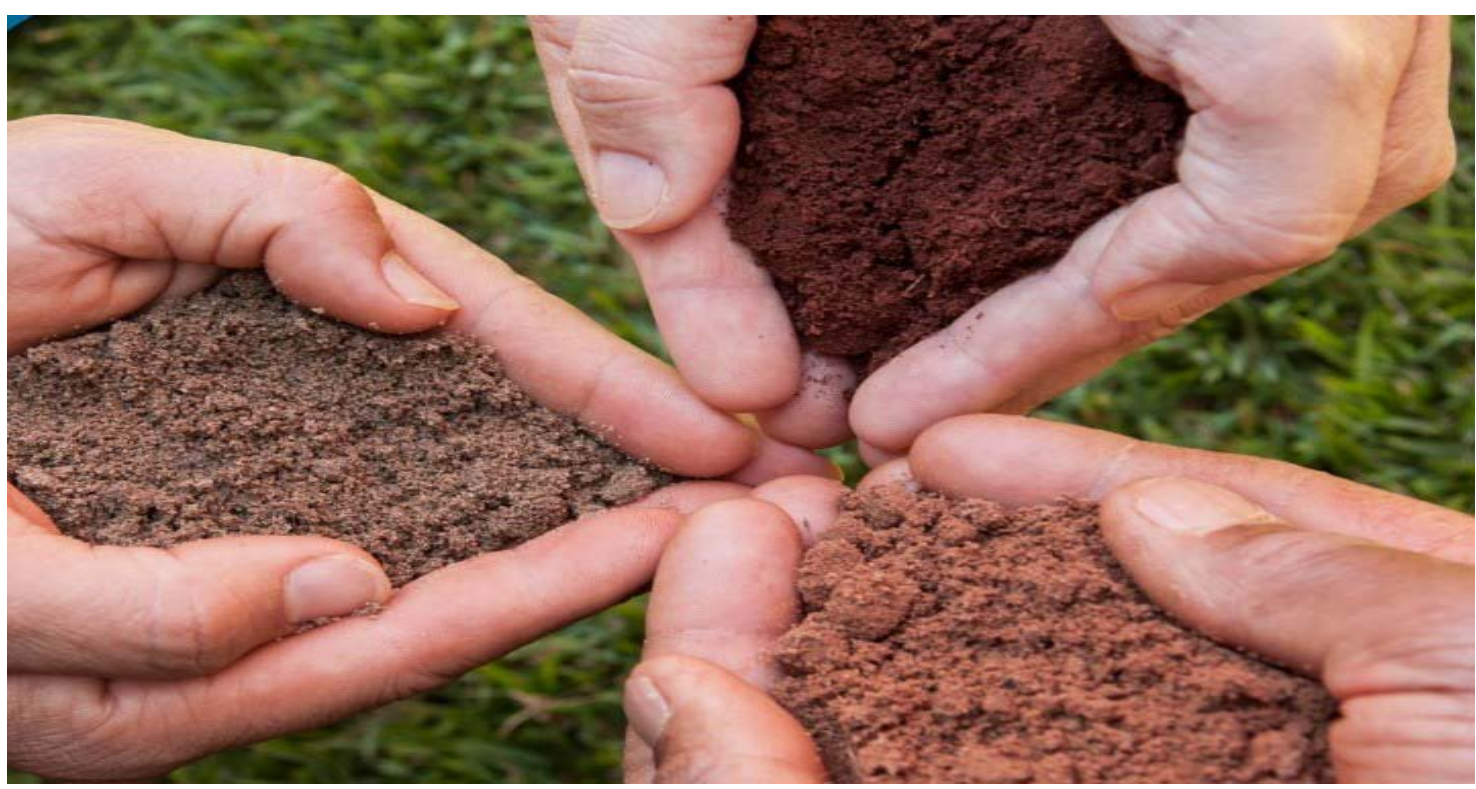

Figura 7. Partículas predominantes nos solos: Areia, argila e silte. Fonte: RESENDE et al., 2002. 
A parte sólida é principalmente mineral, sendo essa fração constituída por minerais primários não intemperizados, classificados de acordo com o tamanho de suas partículas, nas frações cascalho, areia ou silte; e minerais secundários na fração argila.

Especialmente, as partículas do tamanho argila (menor que 0,002 $\mathrm{mm}$ ) afetam as características físicas e químicas do solo, pois exibem comportamento coloidal, apresentando cargas de superfície e grande área específica, sendo a fração que garante a atividade do solo. Os materiais orgânicos são constituídos de resíduos vegetais e animais, parte dos quais são vivos e, aqueles restantes, apresentando diversos estágios de decomposição (VIEIRA, 1975; VIEIRA et al., 1988; SOUZA, 2018).

A parte líquida se constitui essencialmente de água, contendo minerais dissolvidos e materiais orgânicos. Ocupa parte ou quase todo o espaço vazio entre as partículas sólidas, dependendo da umidade do solo. Essa água pode ser absorvida pelas raízes das plantas, evaporada para a atmosfera, drenada ao longo do perfil ou retida na matriz do solo (RESENDE et al., 2002).

A parte gasosa ocupa os espaços vazios não ocupados pela água. É uma porção importante do sistema solo, pois a maioria das plantas exige aeração do sistema radicular (ibidem).

As proporções relativas das três fases variam continuamente e dependem de variáveis como clima, vegetação e manejo. Existe uma correlação com as características físicas e químicas do solo, que determinam a sua qualidade.

As propriedades físicas, tais como a densidade aparente e a textura, influenciam na aeração, na permeabilidade, na infiltrabilidade e na capacidade de retenção de água. As propriedades químicas são as concentrações de componentes orgânicos e inorgânicos que determinam características, tais como a fertilidade do solo e a salinidade, sendo quantificáveis. Tais propriedades, físicas e químicas, exercerão influência sobre a atividade biológica (SCHAEFER et al., 2000).

Portanto, o solo é o local onde ocorre a interação das esferas hidrológicas, biológicas, atmosféricas e geológicas. Dada essa importância, pode ser usado como base para classificação de área degradada e para definir o grau de depauperamento da sua potencialidade.

\subsubsection{Indicadores de qualidade do solo}

Quando ocorre intervenção por atividades antrópicas em uma determinada área, sem as devidas precauções, pode propiciar a sua degradação, podendo ser dividida em três categorias, as quais após a identificação e quantificação, poderão ser utilizadas funcionando como indicadores de qualidade do solo (DORAN e PARKIN, 1994; REINERT, 1998):

\section{a) Degradação física:}

Estão relacionadas às alterações das condições estruturais do solo, ou seja, refere-se à perdas de condições ligadas: 1) à forma, tais como densidade, porosidade, infiltração e aeração; e 2) à estabilidade, tais como a coesão e a resistência dos agregados. Alto grau de compactação, reduzida aeração, alta friabilidade, susceptibilidade à erosão, baixa retenção de água e alteração topográfica do terreno, 
como o selamento, indicam o declínio das condições estruturais do solo e sua degradação física.

Principais indicadores: textura, estrutura, profundidade do solo, do horizonte superficial e das raízes, densidade do solo, taxa de infiltração e capacidade de retenção de água;

\section{b) Degradação biológica:}

Caracterizada, principalmente, pela perda da biodiversidade do solo e pela redução do teor de matéria orgânica, tendo como principal consequência a baixa ou nula atividade da micro (menor de 0,2 $\mathrm{mm}$ em tamanho), meso (de 0,2 a $2 \mathrm{~mm}$ ) e macrofauna (de $2 \mathrm{a}$ $20 \mathrm{~mm}$ ) e flora do solo. A existência de atividade biológica estabelece o processo de ciclagem biogeoquímica, que permite a sustentabilidade do sistema.

Principais indicadores: $\mathrm{C}$ e $\mathrm{N}$ contidos na biomassa microbiana; $\mathrm{N}$ potencialmente mineralizável e taxa de respiração do solo; e

\section{c) Degradação química:}

Reflete os insumos, como a adição desregrada de agroquímicos ao solo; e as saídas, como os nutrientes exportados pela produção agrícola ou pela madeira dos plantios florestais ("drenos florestais"), que reduzem a fertilidade do solo. Processos de acidificação e salinização são exemplos de degradação química do solo.

Principais indicadores: carbono orgânico total, matéria orgânica do solo, $\mathrm{N}$ total; $\mathrm{pH}$; condutividade elétrica; e N, P e K disponíveis.

Dessa forma, pode-se concluir que solos degradados, entre outros, caracterizam-se por apresentar (SÁNCHEZ, 2001):

- Perda de matéria orgânica devido à erosão ou a movimentos de massa;

- Acúmulo de material alóctone recobrindo o solo;

- Alteração negativa de suas propriedades físicas, tais como sua estrutura ou grau de compacidade;

- Alteração de características químicas, devido a processos como salinização, lixiviação, deposição ácida e concentração de poluentes; e

- Morte ou alteração das comunidades de organismos vivos do solo.

Dentro dessa realidade, o modelo de produção convencional ou agroquímico (Figura 8), devido à grande quantidade de energia artificial incompatíveis com o sistema natural, produzindo um volume significativo de resíduos: apresenta maior entropia em relação ao modelo de produção tradicional, como lavouras conduzidas organicamente (Figura 9).

O aumento da energia pode ocorrer de forma lenta e gradual, como nos processos naturais de formação dos solos; ou de forma mais rápida, produzida por meio da interferência antrópica, em função da adição de energia nos sistemas, sejam agrícolas, pecuários, florestais, urbanos ou industriais (KOBIYAMA; MINELLA; FABRIS, 2001).

Para Dias e Griffith (1998), o uso adequado desses indicadores depende de uma visão holística que os integre de forma harmônica a um determinado ecossistema que esteja sendo avaliado. Para isso, é fundamental que sejam definidos valores de referência para a avaliação dos estágios de degradação e, que não sejam padrões fixos, mas sim valores obtidos de áreas próximas, que ainda não tenham sofrido ação antrópica. 
Faz-se necessário maior número de pesquisas para a avaliação dos solos sob o enfoque de degradação, para que rotinas possam ser estabelecidas, de tal forma que o monitoramento e o diagnóstico contemplem o binômio agilidade e facilidade de realização.

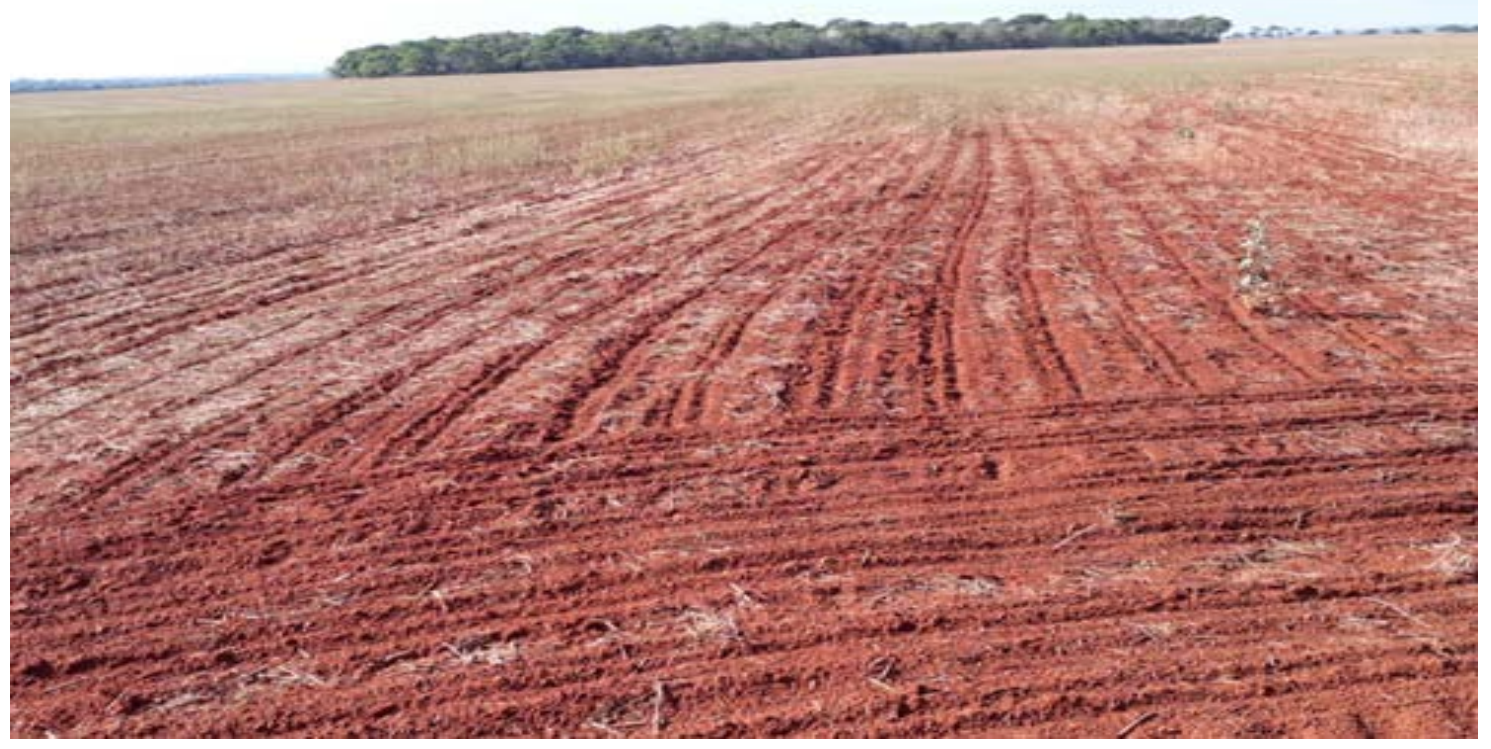

Figura 8. Área de agricultura convencional ou agroquímica preparada para cultivo.

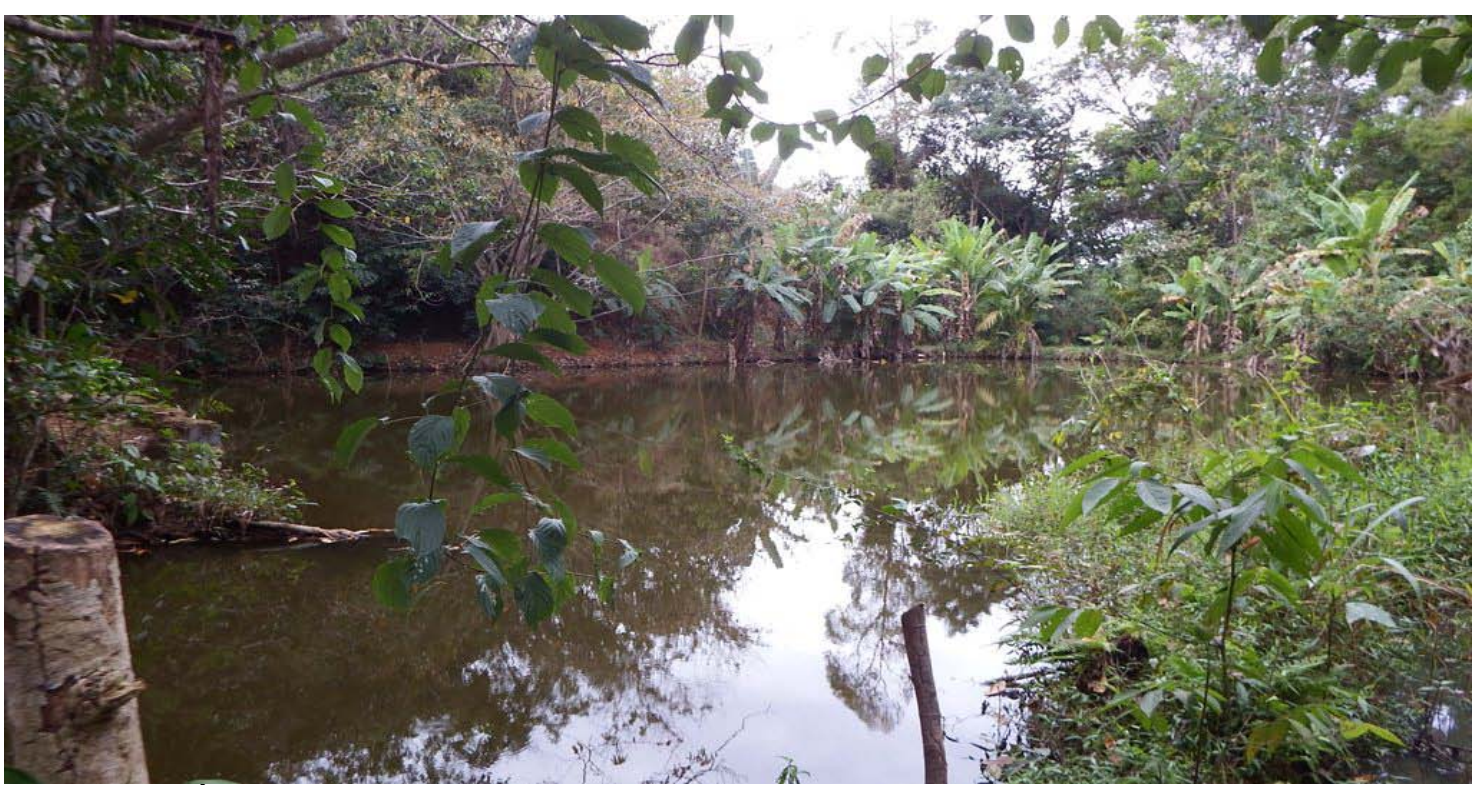

Figura 9. Área de agricultura tradicional, familiar e agroecológica no Sítio Jaqueira Agroecologia, Alegre - ES.

\subsection{Abordagem não segmentada}

Baseia-se na interpretação e quantificação de características ecológicas que determinam a resiliência e a sustentabilidade do ambiente. Qualquer intervenção que possa promover a alteração dos fluxos de energia, na ciclagem de nutrientes e na quantidade e na qualidade da água, resultará em redução da capacidade de suporte e aumento da entropia, promovendo alterações do ciclo biogeoquímico; não cessando o distúrbio, poderá ocorrer a degradação do ambiente (Figura 10). 


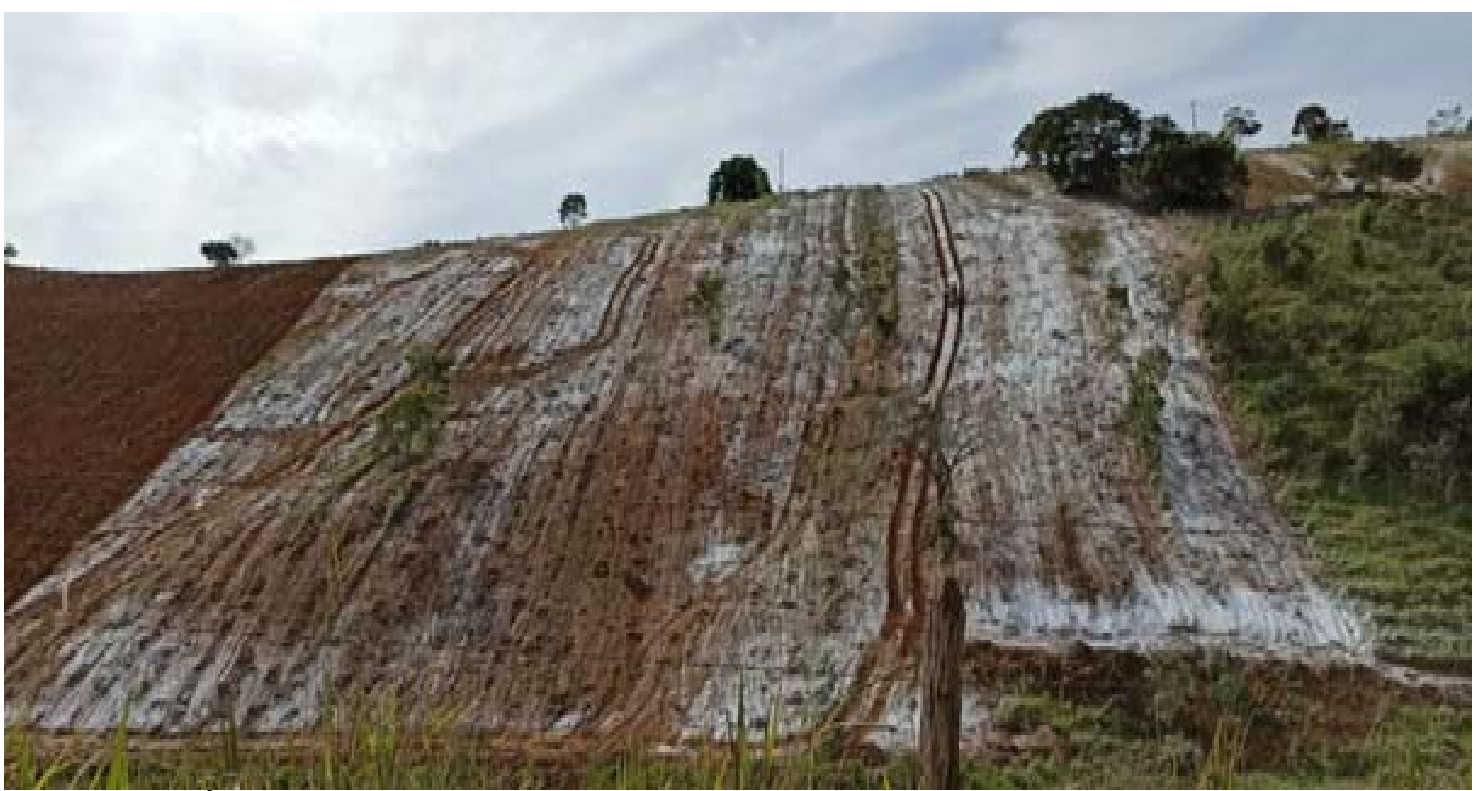

Figura 10. Área degradada com relevo acidentado preparado "morro abaixo".

Para que um determinado sistema seja autossustentável é necessário que haja equilíbrio entre os grupos metabólicos (DIAS, 2003a):

\section{a) Produtores primários:}

São os organismos capazes de absorverem as radiações solares, fixando-as em moléculas orgânicas por meio da fotossíntese;

\section{b) Consumidores:}

São os organismos que utilizam os produtores primários como fonte de alimentação, consumindo os tecidos vegetais, tanto acima da superfície do solo, como também nas camadas inferiores.

Para a manutenção da diversidade, possuem a importante função da dispersão de propágulos das plantas e matéria orgânica, além de promoverem o retorno do carbono para a atmosfera, na forma de dióxido de carbono.

Dentre os organismos que compõem essa cadeia, os animais que comem plantas são consumidores primários; aqueles que comem os consumidores primários são consumidores secundários, como por exemplo, muitos pássaros predadores, peixes e insetos.

Os consumidores terciários comem os secundários, como por exemplo, os carnívoros.

\section{c) Decompositores:}

São os organismos responsáveis pela quebra dos compostos orgânicos dos produtores primários e dos consumidores mortos, possibilitando o retorno dos elementos para a sua forma mineral, sendo reutilizados por meio da reciclagem. A sua grande importância está relacionado ao fato de evitarem o acúmulo de matéria orgânica, o que conduziria à exaustão do carbono da atmosfera.

Como função secundária, também de significativa importância, a de desenvolvimento e manutenção da estabilidade da estrutura do solo, favorecendo a formação de agregados. Consistem basicamente de bactérias, fungos e protozoários (DIAS, 2003a). 
Os microrganismos que contribuem à agregação do solo são todos heterótrofos que necessitam de matéria orgânica como fonte de energia. Os actinomicetos, essenciais na decomposição dos compostos orgânicos, são considerados os mais poderosos agregadores do solo - especialmente por serem os formadores mais eficazes de substâncias húmicas (PRIMAVESI, 1987).

Dessa forma, a estabilidade de um sistema depende da interação complexa entre produção, consumo e ciclagem de gases, solutos e líquidos. Em um sistema natural, duas características são particularmente importantes para a avaliação de um processo de degradação - a capacidade de suporte e a biodiversidade (DIAS, 2003a):

\section{a) Capacidade de suporte:}

Pode ser definida como a densidade máxima teórica que um determinado sistema é capaz de sustentar, considerando tanto o número de espécies como o volume de biomassa. A biomassa está diretamente relacionada ao total de carbono orgânico existente, representando o limite superior do sistema. A magnitude da capacidade suporte está diretamente influenciada e dependente por uma combinação de fatores, tais como regime hídrico, temperatura, radiação solar, solo e topografia.

De acordo com Odum (1988), à medida que aumentam o tamanho e a complexidade de um sistema, o custo energético de manutenção tende a aumentar proporcionalmente; assim, caso o tamanho de um sistema seja dobrado, geralmente torna-se necessário mais que o dobro da quantidade de energia que deve ser desviada para reduzir o aumento na entropia; e

\section{b) Biodiversidade:}

Pode ser definida como o número e a abundância relativa de espécies existentes. Em um conceito mais amplo, pode-se dizer que é o conjunto das variações de base genética que ocorre em todos os níveis de vida, desde as variações dentro de uma única população, até as variações existentes em todas as comunidades de todos os ecossistemas do mundo.

Engloba as plantas, os animais, os microrganismos, os ecossistemas e os processos ecológicos em uma unidade funcional. A diversidade de espécies apresenta dois componentes: 1) a riqueza - definida como o número de espécies presentes; e 2) a uniformidade ou equitabilidade - reflete a abundância relativa ou a forma como os indivíduos encontram-se distribuídos, em número, entre as diferentes espécies existentes. Segundo Odum (1988), a capacidade de resiliência está relacionada à diversidade biológica.

Quanto maior for o tamanho e a complexidade estrutural do ecossistema, a tendência é que maior seja a sua biodiversidade. E maior será sua resiliência.

Após a ocorrência de estresse em um determinado ecossistema, quanto maior for a sua base de informações genéticas, maior será a sua chance da manutenção da estrutura anterior e do funcionamento do sistema de maneira igual ou semelhante à pré-degradação, principalmente devido à sua capacidade de produção de biomassa (retornos crescentes com a escala ou economia de escala), mesmo tendo havido aumento da entropia (Figura 11). 


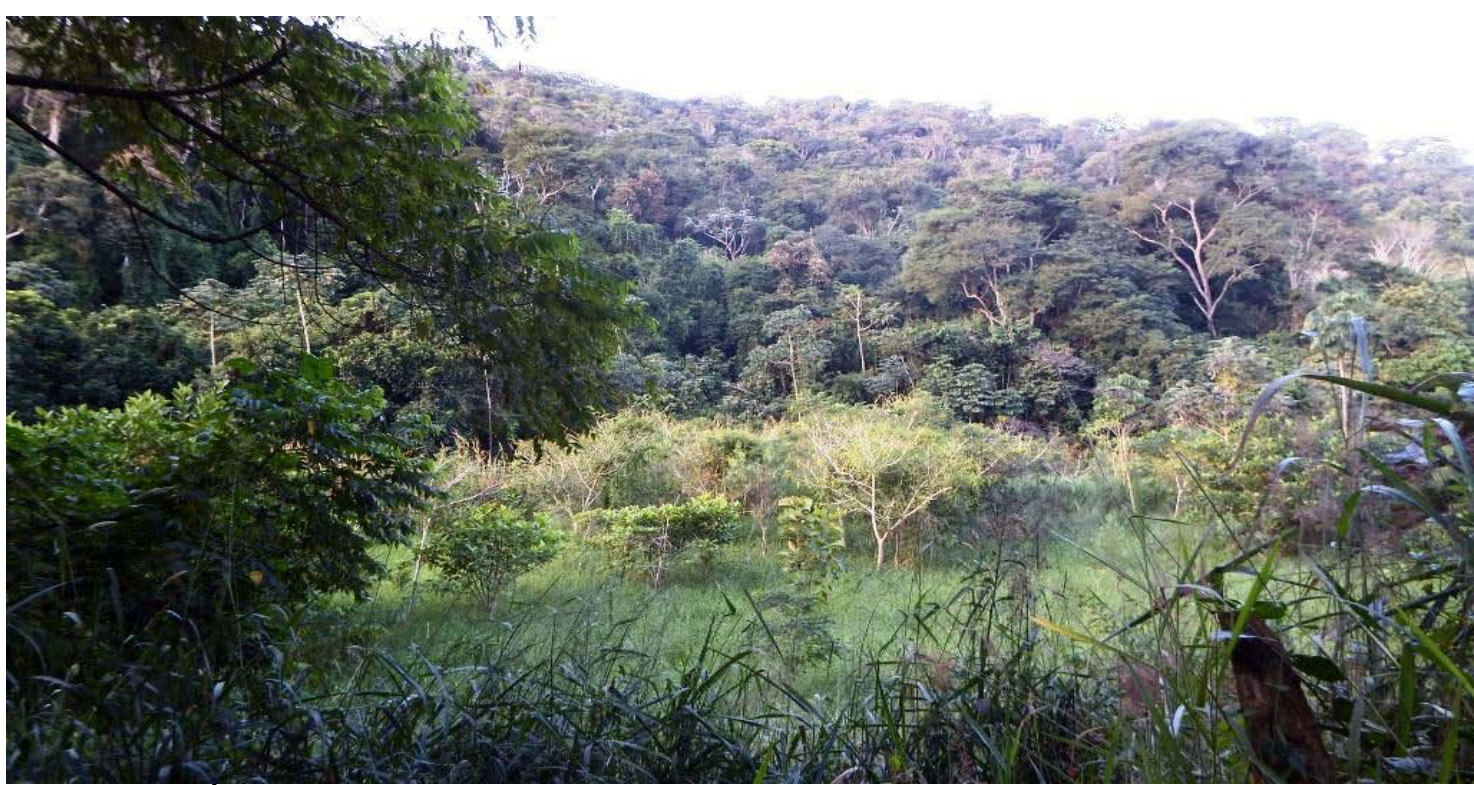

Figura 11. Área de APP ao lado da reserva legal do IF Sudeste de Minas campus Rio Pomba: elevada biodiversidade favorecendo o processo de recuperação.

Este volume de informações que a biodiversidade carrega, representam a resiliência do sistema. Em um sistema natural, existe um equilíbrio entre a produção e o consumo de energia: quando ocorrem perturbações, caso elas não cessem, haverá desequilíbrio, podendo chegar a um colapso catastrófico (retornos decrescentes com a escala ou deseconomia de escala) resultante do maior custo necessário para se livrar da desordem. Ou seja, quando os limites são ultrapassados e a entropia excede a capacidade do ecossistema de dissipá-lo, haverá a redução de seu tamanho e perda de biodiversidade.

Com o fim do estresse, a resiliência do sistema permitirá o restabelecimento da capacidade de suporte aos níveis iniciais, ou próximos àqueles, o mesmo acontecendo à entropia. O tempo necessário para que isto ocorra, está diretamente relacionado com características de cada sistema e a frequência e intensidade de novos estresses. Portanto, a manutenção da biomassa vegetal passa a ter um papel fundamental na sua manutenção, permitindo a fixação de carbono e ao mesmo tempo transformandose num agente de ciclagem de nutrientes, mantendo no sistema um determinado "status" de nutrientes que resulta na sua estabilidade ou sustentabilidade (ODUM, 1988; BARROS; NOVAIS, 1990; DIAS, 2003a; SOUZA, 2018).

Assim, quanto maior for a complexidade de um sistema, tanto maior será a sua capacidade de autorregulação. Entretanto, há que se considerar: à medida que um ecossistema torna-se maior e mais complexo, uma maior parte da sua produção será utilizada para a sua sustentação, diminuindo, proporcionalmente, a parcela da produção bruta que poderia ser destinada ao crescimento.

Quando o equilíbrio entre as entradas e saídas é atingido, o tamanho desse ecossistema não poderá mais aumentar, ou seja, será atingida a sua "capacidade máxima de suporte". Para que esta seja sustentável ao longo do tempo, frente às incertezas ambientais, deve ser calculada considerando valores inferiores: empiricamente, é calculada em torno de $50 \%$ da capacidade máxima teórica de suporte (ODUM, 1988). 
Esse fato pode ser confirmado, por exemplo, nos processos de retirada de madeira sem o devido manejo ou ausência de práticas conservacionistas (Figura 12).

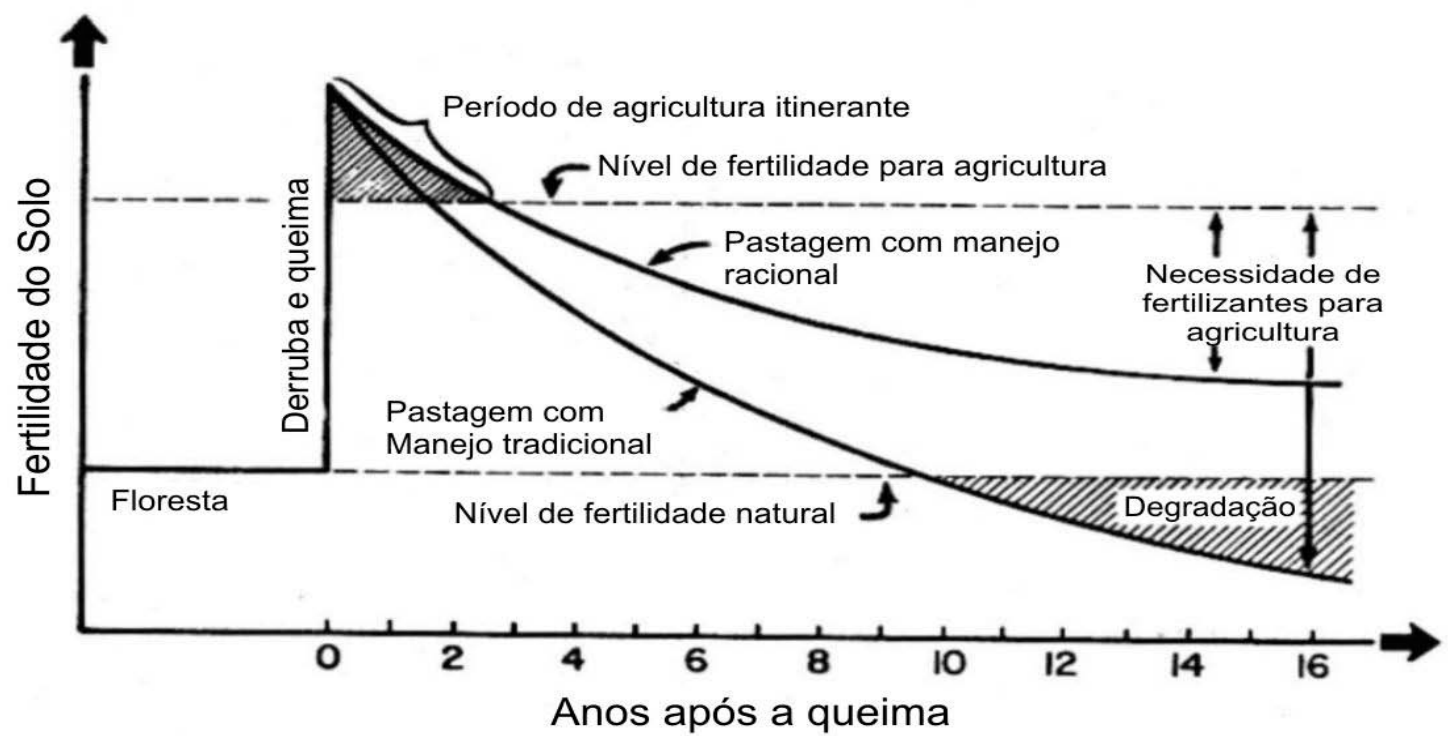

Figura 12. Alterações da fertilidade de um solo pobre, originalmente revestido de floresta, em consequência da derrubada-queima e posterior utilização com agricultura itinerante ou formação de pastagem: manejo tradicional. Fonte: LAMPRECHT, 1990.

Por esse motivo, a devastação decorrente da exploração extrativa de madeira das matas brasileiras de forma predatória, caracterizada pelo nível reduzido de investimento e pela utilização de tecnologia rudimentar, vem ocasionando a extinção de espécies florestais de conhecido valor comercial e, principalmente, ecológico. Como agravante, nessas áreas são introduzidas pastagens, que recebem animais acima da sua capacidade de suporte, onde nenhuma prática conservacionista é adotada, sem nenhuma correção ou reposição de nutrientes ao solo.

Em decorrência desse fato, além do processo de degradação do solo que se inicia, considerando que não seja respeitada a frequência de regeneração para cada espécie, ocorre o comprometimento do seu potencial genético, principalmente pelo fato de que nenhum exemplar adulto das espécies arbóreas é conservado na área em questão (LESCURE; PINTON; EMPERAIRE, 1997).

Esse desmatamento descontrolado tem provocado a ocorrência de inúmeras áreas degradadas e até mesmo, ecossistemas inteiros, principalmente em solos relativamente pobres, como os da Amazônia e do Cerrado brasileiros. Nesse ano de 2020, recordes de incêndios foram quebrados nesses dois biomas: infelizmente, nunca se queimou tantas florestas.

Quando o nível de nutrientes ou de energia de um sistema sofre alteração excessiva, a estabilidade do sistema é afetada, não retornando até que um novo equilíbrio seja atingido naturalmente ou pela ação do homem.

\subsection{A construção de cenários}

Existem várias experiências de sucesso em programas de recuperação. Entretanto, para fazer o monitoramento da recuperação é fundamental acompanhar as alterações 
que se processarão no ecossistema. Considerando o componente "Solo", uma das formas de avaliar as suas perdas por processos erosivos em áreas degradadas ou recuperadas, para a verificação do estádio da sua recuperação, é usar como estratégia a comparação destas áreas com paisagens naturais localizadas na proximidade. Elas representam a memória de uma dada região.

Essa estimativa deve ser feita analisando-se as diversas características do local, incluindo clima, topografia, geologia, cobertura vegetacional, uso e manejo do solo. Servirá também de base para monitoramento e comparações futuras do local. A evidência de que processos erosivos persistem, evidenciam a existência de problemas hidrológicos no local (CURTIA; DYER; WILLIAMS, 1994; SOUZA, 2015).

De acordo com Toy e Daniels (1998), a cobertura vegetacional, a diversidade de espécies e a produtividade da área alterada são habitualmente comparadas com as áreas não perturbadas; ou seja, é uma estratégia que utiliza como abordagem uma "área de referência". Entretanto, essa estratégia é problemática, pois:

a) exige réplicas do ecossistema pré-perturbação; e

b) envolve comparações entre comunidades de plantas nos seus diversos estádios de desenvolvimento e da comunidade original desse solo com distúrbios.

Uma alternativa é a "abordagem utilitária", que avalia se a capacidade do solo perturbado caso corretamente utilizado, poderá sustentar a capacidade de uso do solo pretendido.

Por exemplo, se o uso futuro do solo escolhido for para a atividade cafeicultura, solos recuperados deverão ter produtividade suficiente para garantir ganhos financeiros apropriados para a região, sem efeitos prejudiciais ao ecossistema.

Entretanto, o procedimento correto para o sucesso da recuperação, mais seguro e científico, exige a elaboração de cenários pré e pós-degradação, onde serão estabelecidos os objetivos do processo de recuperação; além do detalhamento minucioso do cenário atual.

Cabe considerar que podem ocorrer duas (2) situações:

a) a área está em sua condição natural, preservada, e será explorada por uma dada atividade; e

b) a área já se encontra degradada e será recuperada para nova destinação: atividade comercial ou voltada para fins de conservação ou preservação ambiental.

Na primeira condição, suponha que tal área será destinada a atividade de mineração e, posteriormente, será recuperada e estabelecida nova destinação. Nesse caso, será realizado elaborado o Cenário pré-degradação, por meio de um EIA, onde será realizado o Diagnóstico Ambiental da área: representará, também, o Cenário atual.

$\mathrm{Na}$ segunda condição, a área já não tem suas condições originais, encontra-se alterada e, ou, degradada. Ou seja: na execução do EIA/RIMA, o diagnóstico ambiental presente considerará as condições atuais, sendo necessária uma vasta pesquisa para se elaborar o Cenário pré-degradação: uma alternativa é buscar nas proximidades áreas que apresentem as mesmas características desse local degradado, como relevo e altitude, observando a vegetação e os variados componentes desse ecossistema, para que se possam pressupor quais eram suas características originais (Figura 13). 


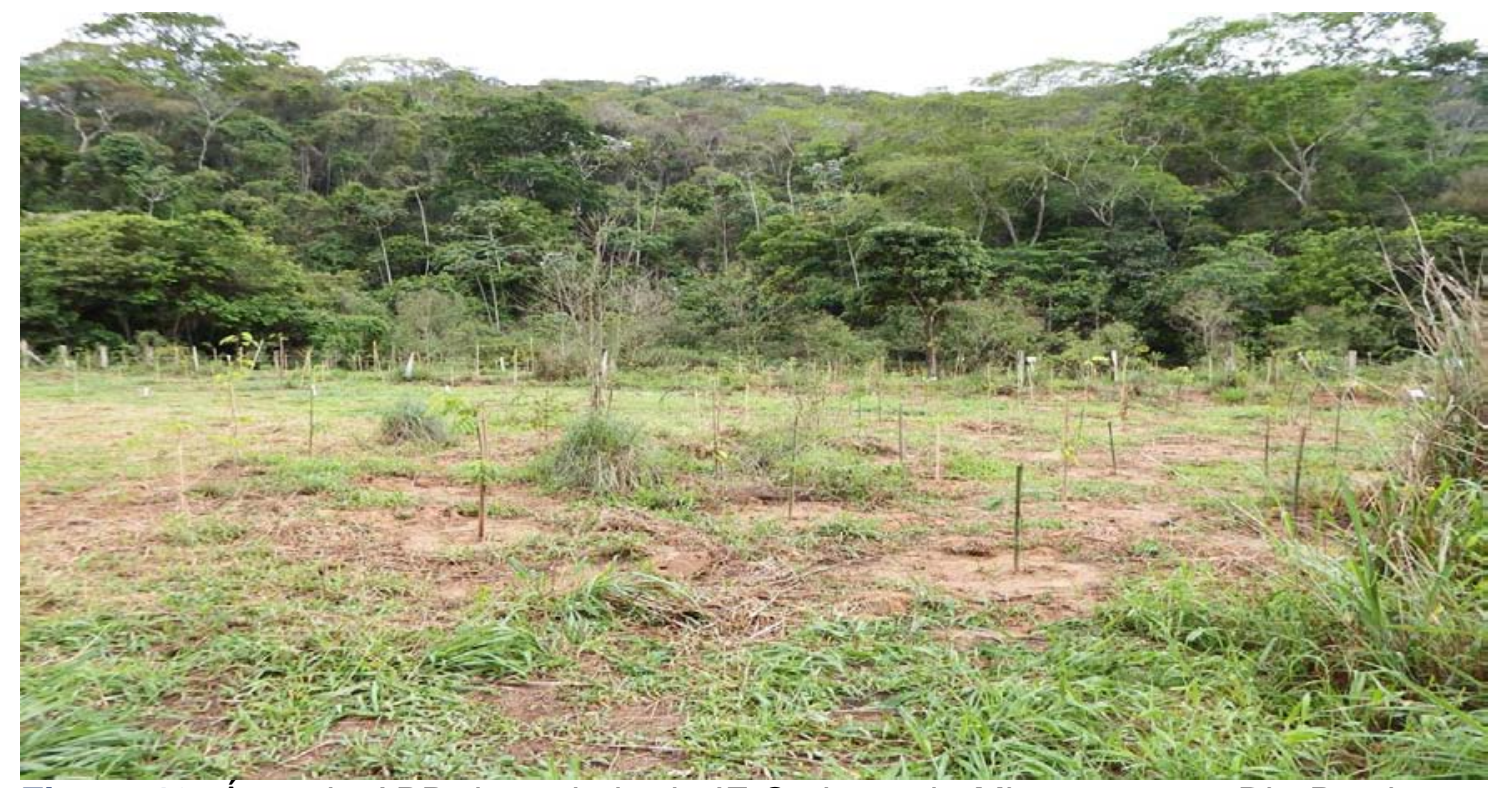

Figura 13. Área de APP degradada do IF Sudeste de Minas campus Rio Pomba em processo de recuperação: vegetação secundária ao fundo estudada para a elaboração do cenário pré e pós-degradação.

Na situação apresentada pela Figura 13, após o levantamento dos dados da área florestada e feito o diagnóstico ambiental da área degradada (Cenário atual), foram elaborados os Cenários pré e pós-degradação.

\subsubsection{Cenário pré-degradação}

O diagnóstico para a elaboração do cenário pré-degradação deve ser realizado a partir de fatores ambientais das áreas de influência e naquelas diretamente afetadas. Deve abranger os componentes destacados durante os Estudos dos Impactos Ambientais (EIA), particularmente aqueles que mereceram destaque no Relatório de Impacto Ambiental (RIMA) do projeto, tais como (SILVA, 1993; 1994a; 1994b; 1998; DIAS, 2003a; SOUZA, 2018):

\section{Meio físico:}

Clima e condições meteorológicas, qualidade do ar, ruído, geologia, geomorfologia, solos, recursos hídricos, hidrogeologia e qualidade das águas;

\section{Meio biótico:}

\section{a) Ecossistemas terrestres:}

- Flora e vegetação (descrição e mapeamento atualizados dos estratos vegetacionais, levantamento fitossociológico para determinação da densidade, abundância, importância e dominância das diversas espécies da vegetação encontradas, identificando aquelas de interesse científico e ameaçadas de extinção);

- Fauna (também, devem ser identificadas com destaque às raras, as ameaçadas de extinção, as de valor econômico e científico, os indicadores de qualidade ambiental, assim como as de interesse epidemiológico) e as possíveis descrições das inter-relações fauna-flora e fauna-fauna na área considerada; e 


\section{b) Ecossistema aquático:}

- Caracterização do estado trófico dos corpos d'água estudados (a caracterização limnológica deverá atender a necessidade de se conhecer as condições física, química e biológica dos cursos d'água a serem aproveitadas nos projetos propostos); e

\section{Meio socioeconômico:}

Dinâmica populacional, uso e ocupação do solo, uso da água, patrimônio natural e cultural, nível de vida, estrutura produtiva e de serviços e organização social.

Após esse levantamento, as informações derivadas devem ser avaliadas por especialistas das diversas áreas relacionadas, para que sejam interpretadas e integradas de forma ordenada e detalhada, sem perder a visão global do ambiente.

\section{A partir de análises e ponderações, surgirão as propostas de recuperação e mitigação de possíveis impactos ambientais. Servirão, também, para a elaboração do cenário pós-degradação. Essas informações devem diagnosticar e representar da melhor maneira possível, com a maior fidelidade, as características do ambiente.}

As informações levantadas podem ser classificadas em quatro categorias (HARRIS; BIRCH; PALMER, 1996; DIAS, 2003a):

\section{Histórico da área:}

Mapas, jornais, revistas, fotografias, livros, registros em cartório, processos jurídicos, entre outros;

\section{Uso corrente:}

Levantamento visual, indicadores econômicos, registros civis, etc.;

\section{Topografia ou arquitetura:}

Levantamentos e mapas topográficos; e

\section{"Status" biogeoquímico:}

Mapas de solos, geologia e hidrologia, vulnerabilidade de águas subterrâneas, monitoramento biológico, amostragens e análises dos diferentes componentes do sistema.

De acordo com DIAS (2003b), o uso de imagem de satélite e de fotografia aérea, quando comparados diferentes períodos são fontes valiosas de informações sobre a evolução de processos de degradação, conservação, desflorestamento e urbanização do ambiente - auxiliam no estabelecimento do potencial de recuperação da área.

Atualmente, há de se considerar a importância do uso de ferramentas tecnológicas e métodos de gestão no processo de monitoramento de projetos de RAD. Com o advento do Sistema de Informação Geográfica (SIG) esse trabalho ficou facilitado, em face do enorme potencial desta ferramenta: permite a análise global do ambiente sob diferentes perspectivas, sem que haja perda do detalhamento necessário para a identificação de problemas pontuais. Ferramentas como drones, programas de geoprocessamento, bancos de dados e canais de comunicação e a sua importância no controle e monitoramento de projetos, contribui de forma significativa para a visualização e interpretação de pontos que não poderiam ser observados anteriormente, sem o uso desses recursos. 
Dessa maneira, depois de sistematizadas as informações, são elaborados os mapas que permitirão a visualização do cenário pré-degradação. Este servirá de referencial e também possibilitará a elaboração do cenário pós-degradação, onde poderá ser avaliado o potencial de recuperação e da determinação dos objetivos dos procedimentos (Figuras 14 e 15).
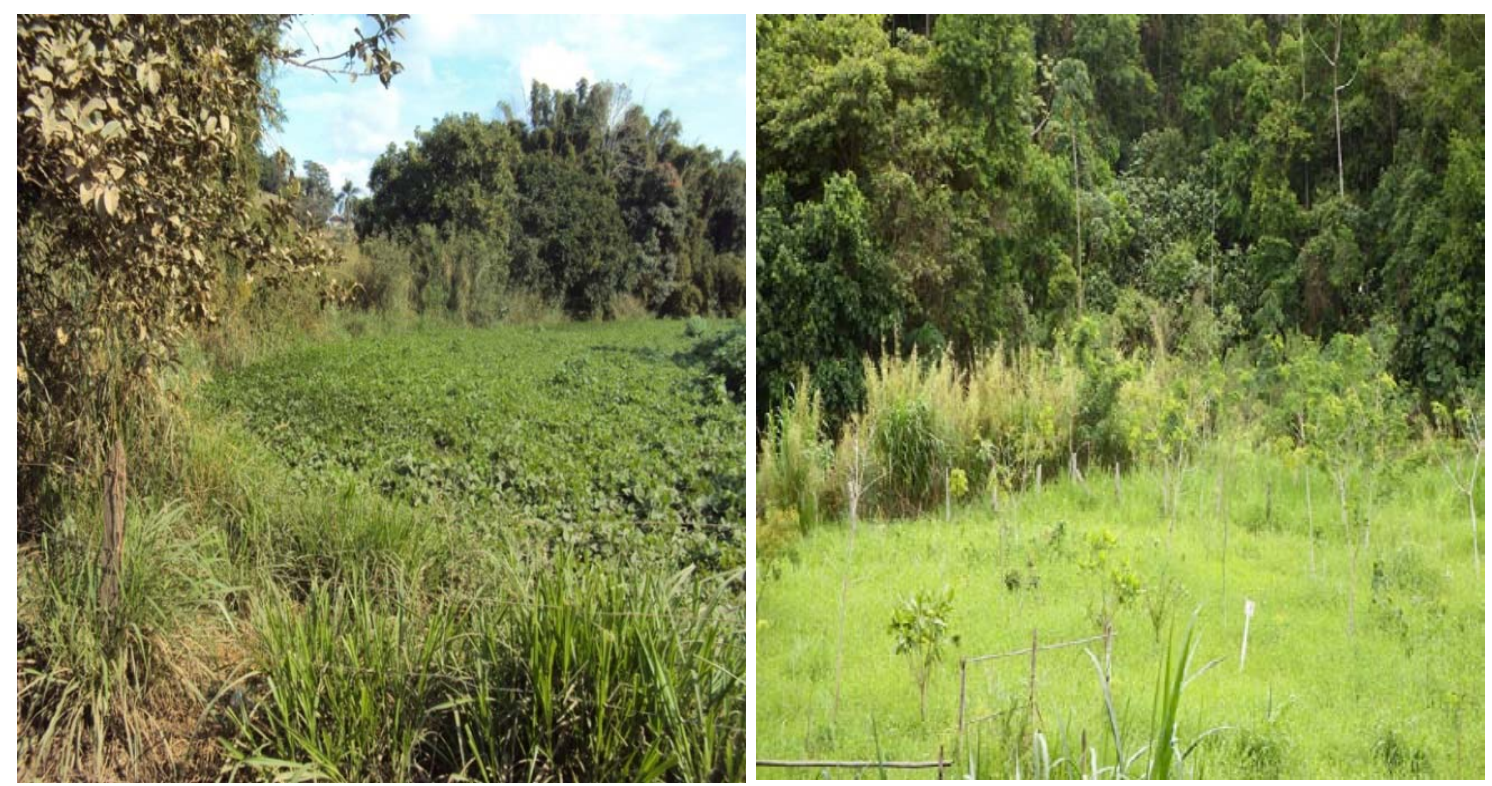

Figuras 14 e 15. Área de APP do IF Sudeste de Minas campus Rio Pomba no início dos procedimentos de recuperação (2011) e dois anos após as intervenções.

Porém, deve-se estar ciente, que a recuperação ambiental não pode reproduzir toda a geologia, o solo, as distinções vegetativas e a beleza cênica que existiram anteriormente à perturbação. Assumidos que aquele solo e as características vegetativas se desenvolveram ao longo do tempo, eventualmente podem retornar a uma condição semelhante àquela de equilíbrio prévio ou, talvez, atinjam uma nova condição de equilíbrio.

A evolução do solo e das propriedades vegetativas afetam os processos hidrológicos e a erodibilidade de taludes, como também a descarga de sedimentos carreada pelo fluxo dos canais (de acordo com Cunha (2003), indica o principal tronco do sistema de drenagem; por exemplo, os rios são definidos como corpos d'água em movimento ambiente lótico, confinados em um canal).

O cenário pré-degradação mostra que é possível examinar mudanças no solo, vegetação e propriedades do canal por algumas décadas, em locais anteriormente recuperados, usando dados da linha de base e fotografias aéreas obtidas antes da perturbação, junto com as atuais medidas no campo (FOSTER, 1982; TOY e DANIELS, 1998; TOY; FOSTER; RENARD, 2002; SOUZA, 2018).

Finalmente, a avaliação por meio de indicadores físicos, químicos e biológicos, dos componentes bióticos e abióticos do ambiente, permite a determinação de seu grau de degradação: os cuidados recaem ao uso de padrões ou referências para a interpretação de indicadores, que devem, preferencialmente, ser originados do local em estudo (discutidos no subcapítulo 4, p. 22: Abordagens para a caracterização de área degradada). 
Assim, o levantamento pré-degradação funciona como peça fundamental para o estabelecimento desses padrões e referências: tanto para quantificar a intensidade de degradação (DIAGNÓSTICO), como também servirá de parâmetro futuro no cenário pós-degradação (PROGNÓSTICO), para o monitoramento e a avaliação do estádio de recuperação (DIAS, 2003a; SOUZA, 2018).

\subsubsection{O cenário pós-degradação}

Para a elaboração do cenário pós-degradação (prognóstico), devem ser realizados levantamentos semelhantes àqueles do cenário pré-degradação. Porém, em função do tipo e das características das atividades que darão origem ao processo de degradação, devem ser incluídas outras avaliações, além de abordagens distintas, por exemplo, a necessidade de monitoramento.

Os levantamentos pós-degradação têm como principal objetivo caracterizar os diferentes ambientes do sistema degradado, de forma a classificá-los quanto:

- Ao grau de degradação;

- Aos riscos ambientais;

- Às estratégias de mitigação de impactos; e

- As potencialidades de uso.

Por esses motivos, a elaboração do cenário pós-degradação, passa a ser uma ferramenta de extrema importância para o estabelecimento dos objetivos da recuperação e para a determinação de estratégias compatíveis com os objetivos predeterminados (DIAS, 2003a).

A recuperação de locais com distúrbios envolve uma variedade de práticas de manejo de curto e longo prazo, normalmente projetadas antes da perturbação, para minimizar os impactos adversos e maximizar o potencial produtivo futuro do local.

Porém, é importante perceber que alguns efeitos de curto prazo, como aumento do escoamento superficial, produção de sedimentos e deslocamento da vida selvagem (flora e fauna), são inevitáveis em atividades perturbadoras de solo, particularmente naquelas que promovem grandes movimentos de solo e retirada da cobertura vegetacional, tais como a mineração, a construção de rodovias e ferrovias, ou mesmo áreas recém-implantadas das atividades de aquicultura e de cafeicultura.

Então, embora o enfoque de metas de recuperação ou reconstrução da pedopaisagem seja de longo prazo, todos impactos hidrológicos, estratégias de revegetação e recuperação após o uso do solo, deve ser incluído um programa ativo de mitigação dos impactos temporários contendo operações diárias e planos contingenciais (TOY e DANIELS, 1998; SOUZA, 2018).

Os riscos ambientais são determinados se levando em consideração o grau de degradação, as características do ambiente propriamente dito e da circunvizinhança, no sentido de delimitação da área de influência e das próprias estratégias de recuperação (DIAS e GRIFFITH, 1998; SOUZA, 2018).

Em geral, medidas de controle do movimento das águas superficiais e dos sedimentos, incluindo na rotina práticas que facilitem a manutenção, são aspectos importantes para evitar impactos ambientais fora do local da perturbação do solo. 
Em circunstâncias onde fortes temporais incidem sobre superfícies áridas, tais como:

- Áreas de pastagens degradadas;

- Taludes expostos nos ambientes urbanos; e

- Áreas mineradas,...

...a erosão causada pelas águas pluviais é agravada pela falta de vegetação.

Como consequência, pode resultar sério problema nos taludes, podendo evoluir de uma ligeira erosão laminar para erosão por sulcos, ravinas e, finalmente, a formação de grandes voçorocas. Inclusive, poderão ocorrer movimentos de massa, tornando-se assim, uma situação de difícil controle.

Por esse motivo, terrenos sem vegetação devem ser protegidos da água corrente originada das partes mais elevadas, de tal forma que os procedimentos de recuperação ambiental, tais como a reposição de matéria orgânica e o replantio de mudas, não sejam perdidos com as chuvas que carregam a camada fértil do solo e do subsolo para cotas mais baixas (fundos de vale, rios, lagos, represas).

A água transportada dentro do local deve ser contida por meio de canais apropriados, com a utilização de estruturas para a contenção de sedimentos, considerando as condições de solo, declividades e clima (os filtros das calhas de drenagem, quando houver, devem ser limpos constantemente). A Figura 16 apresenta área que sofrerá intervenções: em função do avançado nível de degradação, a nascente presente na área, que era perene, tornou-se intermitente.

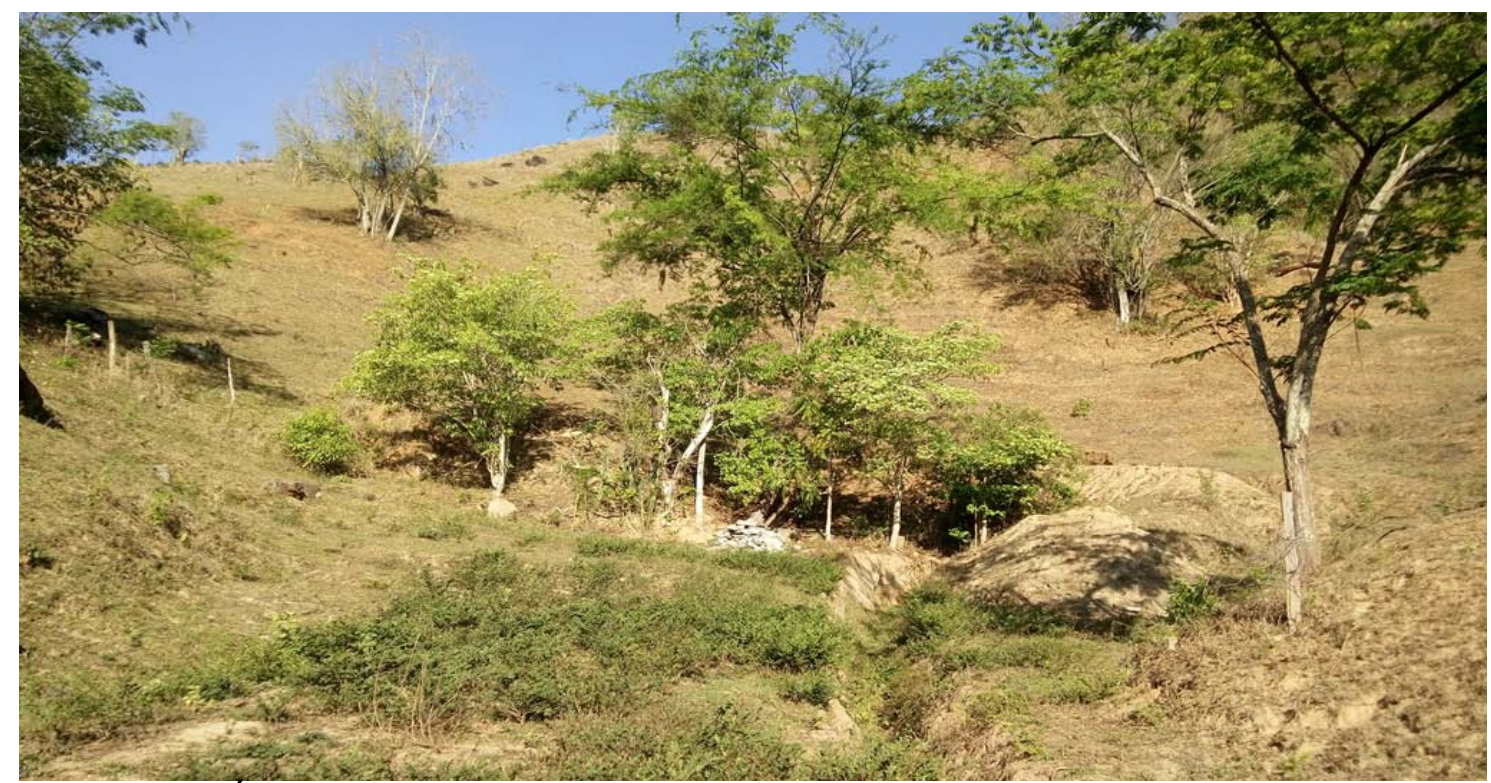

Figura 16. Área de pastagem degradada em relevo movimentado no município de Alegre, ES, com enxurradas e formação de ravinas: nascente com vazão cessada.

Junto com as práticas de gerenciamento de tempestades, de manipulação e de reposição de solo, o plano deve ser revisado e ajustado para prevenir prolongadas exposições altamente erosivas ou estratos potencialmente tóxicos. Em áreas de mineração ou áreas de agropecuária que usam intensivamente agroquímicos, as propriedades físicas e químicas do solo devem ser rigorosamente analisadas antes da perturbação: qualquer material que apresente pequeno risco à qualidade da água, em curto ou longo prazo, deve ser identificado (TOY e DANIELS, 1998; TOY; FOSTER; RENARD, 2002). 
Os esforços de revegetação devem ser simultâneos à perturbação imposta, para que a área total a ser exposta seja reduzida. As valetas (canaletas, calhas, escadas, tubulações, bueiros, fossa) de escoamento de superfície, lagoas de sedimentos e estruturas temporárias, exigem manutenção rotineira para assegurar seu efetivo controle (Figuras 17 e 18).
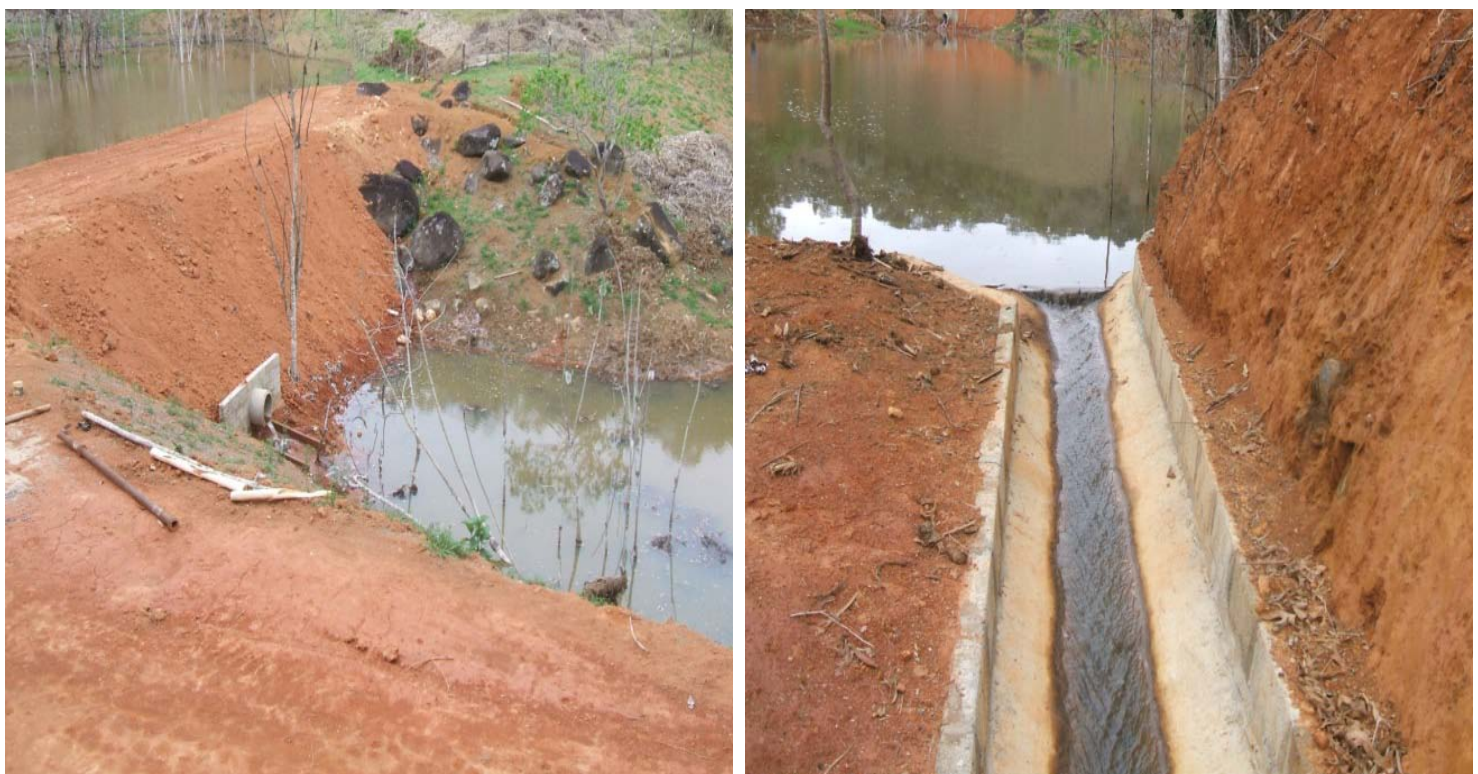

Figuras 17 e 18. Revegetação de taludes e valeta de drenagem (ladrão) de represa da área da invernada do IF Sudeste de Minas campus Rio Pomba.

As canaletas em locais com maiores declividades deverão ser revestidas, por exemplo, com massa de cimento, com o uso de sacos solo-cimento ou argamassa com pedras de mão; ou construir escadas para a dissipação da energia produzida pelo forte movimento das águas (IBAMA, 1990; OLSON; LAL; NORTON, 1994; TOY; FOSTER; RENARD, 2002; SOUZA, 2018).

Este nível de coordenação de manipulação da paisagem exige ajustes diários para reduzir ou substituir alguns passos e efetivamente controlar o escoamento superficial no local (Figura 19).

É recomendável, inclusive para favorecer o abastecimento dos lençóis, construir ao longo do sistema de drenagem pequenos tanques ou bacias de sedimentação (caixas de contenção ou caixas secas ou "barraginhas").

É fundamental para o sucesso dos procedimentos de recuperação de uma dada área, que seja realizado o seu detalhado diagnóstico ambiental. 


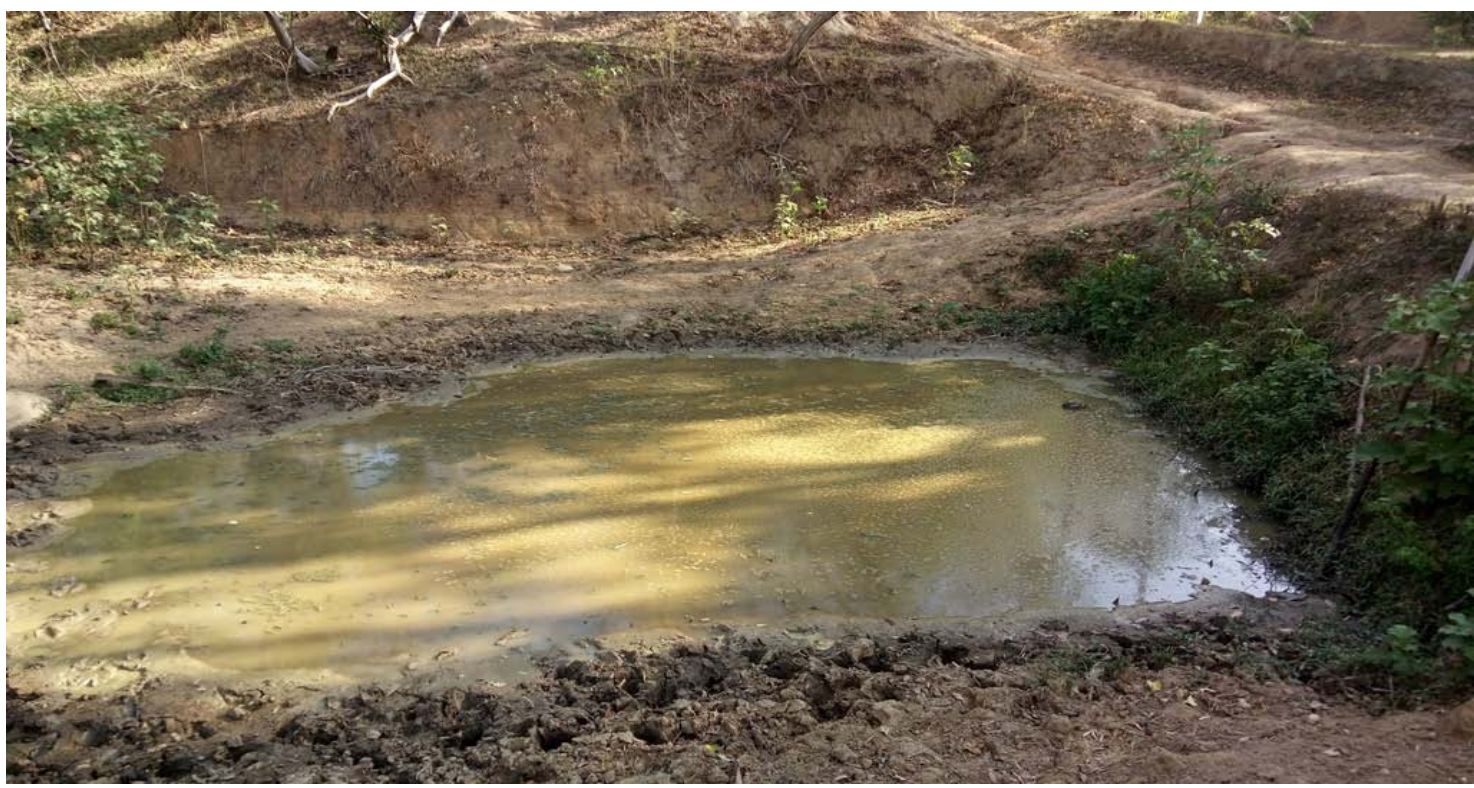

Figura 19. Barraginha em área de pastagem em procedimentos de recuperação.

\section{Diagnóstico ambiental (Cenário atual)}

De acordo com a Resolução CONAMA 001/86, dentro do contexto de um Estudo de Impacto Ambiental (EIA), o diagnóstico ambiental da área de influência do empreendimento deve apresentar uma completa descrição e análise dos recursos ambientais e suas interações, de modo a caracterizar a situação ambiental antes da implantação do projeto (Cenário pré-degradação).

Para que os procedimentos de RAD sejam duradouros, os objetivos de um projeto de recuperação ambiental, a partir de um amplo levantamento, devem considerar além dos aspectos técnicos e legais, também, os aspectos ambientais, sociais, culturais, econômicos e éticos - que são identificados nessa fase do diagnóstico ambiental.

A partir dessa análise, o ambiente passa a ser avaliado de tal forma que possam ser geradas informações a respeito de suas características anteriores ao processo de degradação (cenário pré-degradação), o qual poderá fornecer importantes informações sobre o potencial de recuperação do ambiente, no cenário pósdegradação (ou seja, no futuro, o prognóstico).

Dessa forma, o diagnóstico ambiental deverá retratar o cenário e a qualidade ambiental atual da área de abrangência dos estudos, indicando as principais características dos diversos fatores que compõem o sistema ambiental, de forma a permitir o entendimento da dinâmica e das interações existentes entre os meios físico, biótico e socioeconômico da área diretamente afetada (Figura 20).

No Estado do Espírito Santo, o Instituto Estadual de Meio Ambiente e Recursos Hídricos (IEMA), realiza tal etapa visando atender as diretrizes acima especificadas e cumprir o Termo de Referência estabelecido por esse órgão.

Nos dias atuais, na execução do Estudo de Impacto Ambiental do Projeto de Implantação da Central de Tratamento de Resíduos - Terramar, o diagnóstico ambiental foi subdividido em três tópicos principais (IEMA, 2020):

- Meio Físico: climatologia, geologia, geomorfologia, recursos hídricos e qualidade das águas superficiais e ruídos; 
- Meio Biótico: vegetação e fauna; e

- Meio Antrópico: dinâmica populacional, economia, infraestrutura, uso e ocupação do solo, organização social.

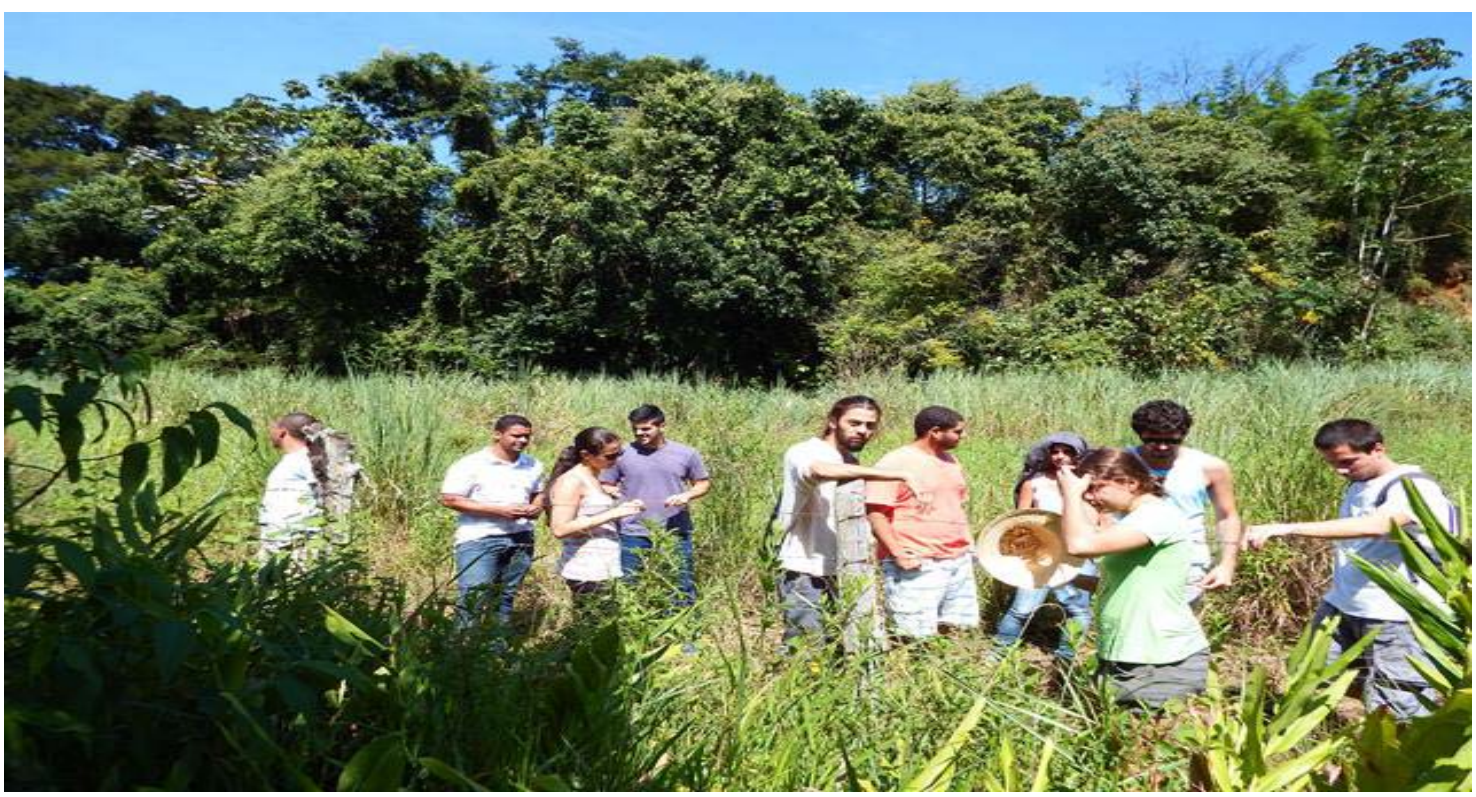

Figura 20. Alunos do curso de Agroecologia (disciplina RAD) realizando o diagnóstico ambiental de APP a ser recuperada: IF Sudeste de Minas campus R. Pomba.

Segundo o IEMA (2020), o desenvolvimento do Diagnóstico Ambiental baseou-se em três vertentes fundamentais:

- Levantamento de Dados Secundários;

- Sensoriamento Remoto; e

- Levantamento de Campo (Dados Primários).

O presente documento sugere que sejam adotados os seguintes procedimentos para a boa execução do diagnóstico ambiental de um dado projeto:

- Identificar os problemas ambientais adversos que podem ser esperados;

- Incorporar, nas ações de desenvolvimento, medidas mitigadoras apropriadas;

- Identificar os benefícios e prejuízos do projeto, bem como sua aceitabilidade pela comunidade;

- Identificar problemas críticos que requerem estudos ou monitoramento posteriores (auxiliando, dessa forma, nos procedimentos de monitoramento da recuperação ambiental);

- Examinar e selecionar alternativas ótimas para várias opções viáveis (evita o surgimento de novas áreas degradadas);

- Envolver o público no processo de tomada de decisões relativas às questões ambientais, para entender seu papel, suas responsabilidades e as relações existentes entre estas.

Cabe considerar, que a execução de uma AIA segue, de maneira geral, as seguintes etapas:

- Desenvolvimento de um completo entendimento da ação proposta;

- Aquisição do conhecimento técnico do ambiente a ser afetado;

- Determinação dos possíveis impactos sobre as características ambientais, 
quantificando, quando possível, as mudanças; e

- Apresentação dos resultados da análise de maneira tal que a ação proposta possa ser utilizada em um processo de decisão.

6. Principais etapas para o sucesso da recuperação de áreas degradadas

Inicialmente, breves comentários sobre LICENCIAMENTO AMBIENTAL (EIA/RIMA, RCA/PCA, AAF):

\section{LICENCIAMENTO AMBIENTAL:}

Licenciamento ambiental é o procedimento administrativo realizado pelo órgão ambiental competente, que pode ser federal, estadual ou municipal, para licenciar a instalação, ampliação, modificação e operação de atividades e empreendimentos que utilizam recursos naturais, ou que sejam potencialmente poluidores ou que possam causar degradação ambiental.

O licenciamento é um dos instrumentos de gestão ambiental estabelecido pela lei Federal n. ${ }^{\circ}$ 6938, de 31/08/81, também conhecida como LEI DA POLÍTICA NACIONAL DO MEIO AMBIENTE.

\section{ESTUDO DE IMPACTO AMBIENTAL - EIA:}

É um documento de natureza técnica, que tem como finalidade demonstrar a viabilidade ambiental e avaliar os impactos ambientais gerados por atividades e/ou empreendimentos potencialmente poluidores ou que possam causar degradação ambiental. Deverá contemplar a proposição de medidas mitigadoras e de controle ambiental, garantindo assim o uso sustentável dos recursos naturais. Foi instituído pela Resolução CONAMA 01/86, sendo solicitado durante a Licença Prévia.

\section{RELATÓRIO DE IMPACTO AMBIENTAL - RIMA:}

Deve refletir as conclusões do EIA, e deve ser apresentado de forma objetiva e de fácil compreensão. As informações devem ser apresentadas em linguagem acessível, acompanhadas de mapas, tabelas e gráficos de modo a que as vantagens e desvantagens do projeto, bem como todas as consequências ambientais de sua implantação, fiquem evidenciadas.

\section{RELATÓRIO DE CONTROLE AMBIENTAL - RCA:}

É o documento exigido em caso de dispensa do EIA/Rima ou durante a Licença de Instalação É por meio do RCA que o empreendedor identifica as não conformidades efetivas ou potenciais decorrentes da instalação e da operação do empreendimento para o qual está sendo requerida a licença.

\section{PLANO DE CONTROLE AMBIENTAL - PCA:}

É o documento por meio do qual o empreendedor apresenta os planos e projetos capazes de prevenir e/ou controlar os impactos ambientais decorrentes da instalação e da operação do empreendimento para o qual está sendo requerida a licença, bem como para corrigir as não conformidades identificadas. O PCA é sempre necessário, independente da exigência ou não de EIA/Rima, sendo solicitado durante a Licença de Instalação.

\section{AUTORIZAÇÃO AMBIENTAL DE FUNCIONAMENTO - AAF:}

É obrigatória para as empresas que se enquadram nas classes 1 e 2, por serem menores no tamanho e no nível de poluição. A classificação dos empreendimentos é definida pelo Conselho Estadual de Política Ambiental através da Deliberação Normativa $\mathrm{n}^{\circ} 74$. Ela classifica, detalhadamente, as diversas atividades. 
Mesmo com a geração de conhecimentos e informações nas últimas décadas, com o crescimento da legislação e fiscalização pelos órgãos ambientais, das campanhas de educação e gestão ambiental, a perpetuação dos casos de degradação persiste, principalmente, em face da priorização que o homem destina aos benefícios imediatos de suas ações, privilegiando os lucros e o crescimento econômico a custos elevados e relegando, como fosse uma questão secundária, a capacidade de recuperação dos ecossistemas.

Assim, para Coelho (2001), os impactos ambientais são temporais e espaciais, incidindo de forma diferenciada em cada ecossistema, alterando as estruturas das classes sociais e reestruturando o espaço. Para Bernardes e Ferreira (2003), dentro dos atuais modelos de produção que exploram os recursos naturais, afetam diretamente o meio ambiente, muitas vezes sofrendo impactos negativos irreversíveis ou de difícil recuperação. De fato, para a melhor compreensão de impactos ambientais como processo, é necessário que seja compreendida a história sistêmica de sua produção, o modelo de desenvolvimento adotado e os padrões internos de diferenciação social.

Ao que tudo indica, existe uma correlação negativa entre a taxa de crescimento de uma população humana e a sua qualidade de vida. Dessa forma, as questões macroeconômicas de distribuição de riqueza, recursos e tecnologia, devem caminhar como prioridade no plano das preocupações mundiais. Dentro desse contexto, em praticamente todas as partes do mundo, surgiu a preocupação de promover mudança de comportamento do homem em relação à natureza, a fim de harmonizar interesses econômicos e conservacionistas, com reflexos positivos junto à qualidade de vida de todos (MILANO, 1990, apud SILVA, 1998).

Inicia-se, nos anos da década de 1960, um movimento internacional que se contrapunha a essa situação, evidenciando um início de preocupação com as questões ambientais. Por força de movimentos ambientalistas, em 1969, nos Estados Unidos, o Congresso americano editou a "National Environmental Policy Act" - NEPA, uma Lei de Política Ambiental aprovada em janeiro de 1970, donde surgiu a avaliação de impactos ambientais (AIA). Esta lei foi criada em face à necessidade de se adequar novos métodos de avaliação de projetos que considerassem, além dos custos e benefícios sociais, a proteção ao meio ambiente e o uso racional dos recursos naturais (ANDREAZZI; MILWARD-DE-ANDRADE, 1990; SILVA, 1998).

Segundo Lima (1997), os anos da década de 1970, figuram como um marco de emergência de questionamentos e manifestações ecológicas, em nível mundial. Nesse período, a sociedade, as instituições e os governos, passam a defender a inclusão dos problemas ambientais na agenda do desenvolvimento das nações e das relações internacionais como um todo. Tais preocupações "refletem a percepção de um conflito crescente entre a expansão do modelo de crescimento econômico, de base industrial, e o volume de efeitos desagregadores sobre os ecossistemas naturais". O conjunto de impactos ambientais, até então percebidos como resíduos inofensivos do progresso e da expansão capitalista passam a assumir uma nova dimensão: a despertar atenção, interesse e novas leituras.

Dessa forma, a avaliação de impactos ambientais, etapa fundamental para o sucesso da recuperação de áreas degradadas, dada a relevância do fator antrópico como causador de degradação, deve considerar e avaliar os aspectos socioeconômicos e culturais, além dos aspectos biológicos, envolvidos e afetados por esses processos, em face à sua indivisibilidade. 
A avaliação ambiental objetiva, essencialmente, fundamentar e otimizar processos decisórios envolvendo atividades transformadoras, antrópicas ou não (TAUK; GOBBI; FOWLER, 1995). Quando se fala em avaliação, automaticamente pensa-se em um direcionamento para que se atribua um valor numérico tendo como referência um modelo padrão. No entanto, a avaliação relacionada a fatores ambientais está fundamentada no que certas atividades econômicas podem estar promovendo, como alterações positivas ou negativas para o meio ambiente.

Neste sentido é fundamental que saiba avaliar se é mais importante implantar esta atividade que promoverá alteração ambiental, ou não realizá-la e optar pela permanência do ambiente saudável, evitando soluções onerosas para esses problemas que surgiriam. Em áreas em produção, como pastagens e cafezais, implantados em locais onde deveriam ser APPs, e mal manejados, existem novas opções de condução e recuperação!

Segundo Moreira (1985), a avaliação de impactos ambientais (AIA)...

...é um instrumento de política ambiental formado por um conjunto de procedimentos capaz de assegurar, desde o início do processo, que se faça um exame sistemático dos impactos ambientais de uma ação proposta (projeto, programa, plano ou política) e de suas alternativas, e que os resultados sejam apresentados de forma adequada ao público e aos responsáveis pela tomada de decisão, e por eles devidamente considerados.

Isto significa conhecer os componentes ambientais e suas interações, caracterizando, assim, a situação ambiental dessas áreas antes da implantação do projeto. O mais importante, é que estes resultados servirão de base à execução das demais atividades (CUNHA e GUERRA, 1999). Convém ressaltar, que nas definições de AIA, algumas dão ênfase aos componentes políticos e de gestão ambiental.

Para Biswas e Gepeng (1987), dentre os objetivos da AIA, podem ser destacados:

- Identificar os problemas ambientais adversos que podem ser esperados;

- Incorporar, nas ações de desenvolvimento, medidas mitigadoras apropriadas;

- Identificar os benefícios e prejuízos do projeto, bem como sua aceitabilidade pela comunidade;

- Identificar problemas críticos que requerem estudos ou monitoramento posteriores (auxiliando, dessa forma, nos procedimentos de monitoramento da recuperação ambiental);

- Examinar e selecionar alternativas ótimas para várias opções viáveis (evita o surgimento de novas áreas degradadas);

- Envolver o público no processo de tomada de decisões relativas às questões ambientais, para entender seu papel, suas responsabilidades e as relações existentes entre estas.

A execução de uma AIA segue, de acordo com Cunha e Guerra (1999), e Souza (2004; 2018), de maneira geral, as seguintes etapas:

- Desenvolvimento de um completo entendimento da ação proposta;

- Aquisição do conhecimento técnico do ambiente a ser afetado;

- Determinação dos possíveis impactos sobre as características ambientais, quantificando, quando possível, as mudanças; e 
- Apresentação dos resultados da análise de maneira tal que a ação proposta possa ser utilizada em um processo de decisão.

O fato é que o sucesso dos procedimentos de recuperação, para que, além de atender aos aspectos ambientais e legais, também proporcionem vantagens socioeconômicas, dependerá da realização de diversos procedimentos e a obediência a diversas etapas.

A Resolução n. 001/86 do CONAMA definiu os tipos de empreendimentos sujeitos à AIA e o conteúdo mínimo do EIA e do RIMA (Relatório de Impacto Ambiental) necessário ao licenciamento das atividades consideradas impactantes. Dessa forma, estabeleceu quatro atividades técnicas a serem abordadas nos EIAs (MOREIRA, 1985; MACHADO, 1987; SOUZA, 2004; 2018):

- Diagnóstico ambiental da área de influência do projeto (meios físico, biótico e antrópico);

- Análise dos impactos ambientais do projeto, contemplando as alternativas tecnológicas e de localização do projeto, confrontando-as com a hipótese da não execução do projeto;

- Definição das medidas mitigadoras dos impactos negativos ou potencializadoras dos impactos positivos, avaliando a eficiência de cada uma delas; e

- A elaboração de programas de acompanhamento e de monitoramento de impactos positivos e negativos, incluindo os parâmetros a serem considerados.

Inicialmente, deve ser feita uma avaliação do RIMA e, ou do PRAD, para que possam ser revistos os objetivos iniciais.

Verifica-se a necessidade de alterações resultantes das atividades produtivas e da própria evolução da pesquisa durante o período de exploração. Devem ser respeitados as exigências legais e orientar-se pelas mudanças propostas necessárias identificadas por esses dois documentos: essa fase pode ser considerada o pré-planejamento, posto ser nela que serão preparados os planos de recuperação.

Nele, deve conter uma orientação, passo a passo, para os procedimentos que serão empregados para recuperar as áreas degradadas por uma dada atividade, devendo obedecer as seguintes e principais etapas, que deverão ser realizadas de forma cronológica (IBAMA, 1990; HARRIS; BIRCH; PALMER, 1996; TOY e DANIELS, 1998; SOUZA, 2004):

\subsection{Etapas/procedimentos para um projeto de recuperação de áreas degradadas}

Para o sucesso dos procedimentos de RAD, várias etapas precisam ser respeitadas. A não observância a essas etapas resultarão em problemas que poderão colocar em risco o resultado final e a sustentabilidade do empreendimento; ou mesmo desencadear uma série de impactos ambientais que poderão agravar a situação préexistente. Assim, a primeira etapa deve considerar o objetivo, a escala e a abrangência da área que sofrerão as intervenções.

\subsubsection{Objetivo, escala e abrangência}

De acordo com Martins (2009), antes do início da elaboração de um projeto de recuperação de uma determinada área degradada, a primeira etapa consiste em definir qual é o OBJETIVO que se pretende para o referido local. Uma área degradada pela atividade de cafeicultura, por exemplo, caso seja utilizada para o replantio dessa mesma cultura, seguirá determinados procedimentos (Capítulo III); caso seja utilizada, 
por exemplo, para a implantação da atividade de aquicultura, seguirá roteiro semelhante (Capítulo II), mas não o mesmo.

Outra questão fundamental, definido o objetivo, será determinar a ESCALA do projeto. Muitos projetos fracassam pela não observação a essa questão. Todas as etapas que se seguirão tem um custo. De nada adiantaria iniciar um projeto e não terminá-lo: todo o investimento será perdido e a área permanecerá degradada.

Dependendo do objetivo e da escala do projeto, há de se considerar a sua ABRANGÊNCIA (MARTINS, 2009): se algo apenas pontual, como uma pequena represa para a atividade de aquicultura ou uma pequena área destinada à atividade de cafeicultura, os procedimentos serão mais simples, mas não menos importantes. Contudo, se envolver uma escala média, como toda uma pequena propriedade rural (adequação ambiental); ou uma escala ampla, como uma microbacia hidrográfica ou mesmo um projeto como o de RAD da bacia do rio Doce, pela Fundação Renova, necessitam de uma visão global - holística e sistêmica.

Dessa forma, serão avaliados os possíveis cenários que poderão ser estabelecidos: há de se elaborarem os cenários pré e pós-degradação. Então, será necessária a realização dos Estudos de Impactos Ambientais (EIA), onde se descreverá o Diagnóstico Ambiental e se proporá o Zoneamento Ambiental da área.

Dessa forma, serão identificadas e delimitadas as características e situações ambientais (Figura 21), considerando atributos selecionados, como sugerem Martins (2009) e Souza (2018): estado de degradação, tipo de solo, vegetação remanescente, características do entorno da área a ser recuperada, matriz vegetacional onde estão inseridos, forma e tamanho da microbacia hidrográfica, entre outros. Tais procedimentos visam reduzir os custos do projeto e aumentar sua eficiência em temos ecológicos.

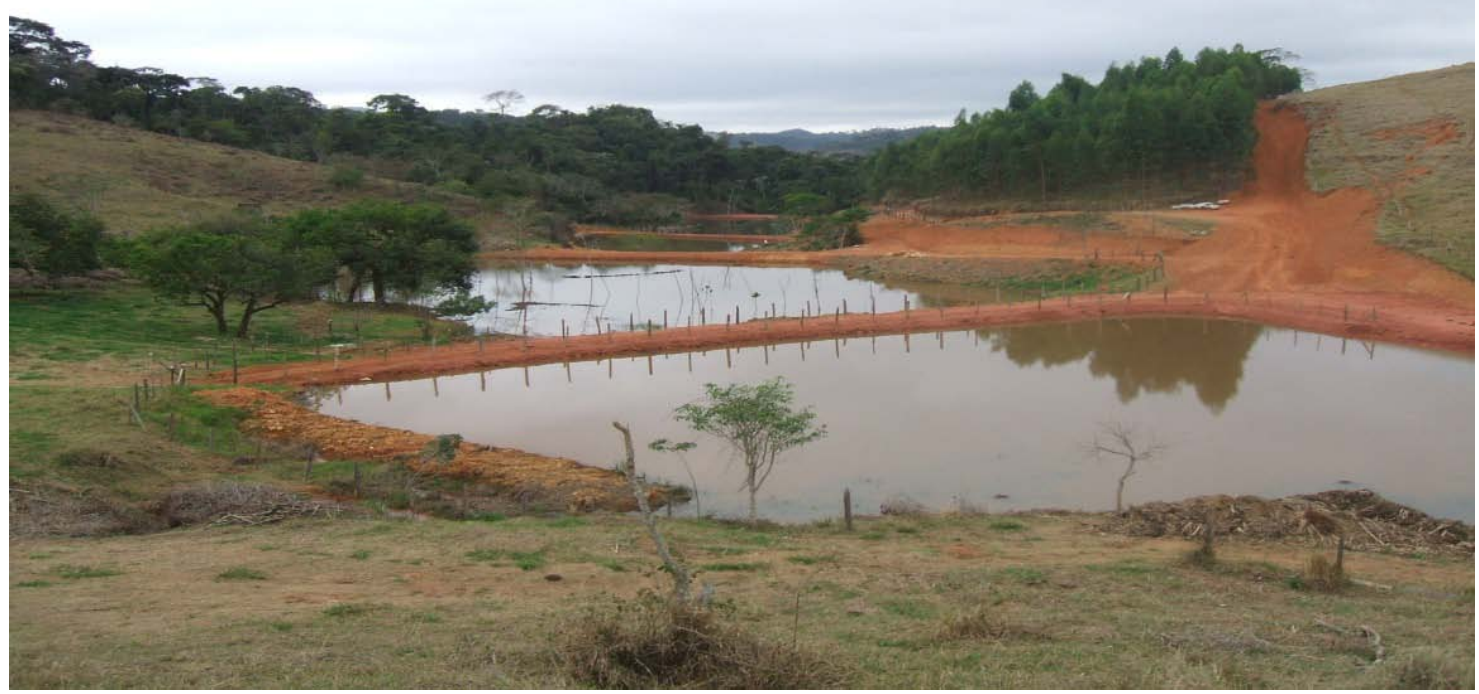

Figura 21. Construção de açudes visando a recarga de aquíferos no IF Sudeste de Minas campus Rio Pomba.

Durante o processo de elaboração do EIA e na fase de levantamento e planejamento das técnicas e dos procedimentos de recuperação de áreas degradadas a serem utilizados, quanto maior for a abrangência do projeto, maiores serão as chances de se obter sucesso em tais procedimentos. Para isso, alguns passos, necessariamente, 
devem ser observados (MACHADO, 1987; SILVA, 1998; SOUZA, 2004; SOUZA, 2018).

\subsubsection{Caracterização do local}

As propriedades físicas e químicas da área do distúrbio, dentro de um particular cenário ambiental, influenciam significativamente o planejamento e a prática de recuperação propriamente dita, podendo significar o sucesso dos procedimentos.

A caracterização do local, fundamental para a elaboração do diagnóstico ambiental, usualmente, inclui análises das condições climáticas, das condições geológicas, da topografia, dos solos, da vegetação e da hidrologia. Sabe-se que o sistema ambiental possui funções abertas e inter-relacionadas entre seus componentes. Desta forma, mudanças nas características destes locais, podem ter ramificações ao longo do tempo.

É necessária uma abordagem segmentada de cada um dos principais fatores envolvidos, analisando as áreas de influência direta e indiretamente afetadas. Deverá conter:

\section{Informações gerais:}

Nome do empreendimento; identificação da empresa responsável; histórico do empreendimento; tipo de atividade e porte do empreendimento; síntese dos objetivos do empreendimento, sua justificativa e a análise de custo-benefício; levantamento da legislação federal, estadual e municipal incidente sobre o empreendimento em qualquer de suas fases; entre outros;

\section{Descrição do empreendimento:}

Apresentar a descrição do empreendimento nas fases de planejamento, de implantação, de operação e, se for o caso, de desativação;

\section{Área de influência:}

Apresentar os limites da área geográfica a ser afetada direta ou indiretamente pelos impactos, denominada área de influência do projeto;

\section{Fatores ambientais:}

Deve ser feita a caracterização dos meios físico, biótico e socioeconômico;

\section{Qualidade ambiental:}

Em um quadro sintético, expor as interações dos fatores ambientais físicos, biológicos e socioeconômicos;

\section{Análise dos impactos ambientais:}

Apresentação da análise (identificação, valoração e interpretação) dos prováveis impactos ambientais nas fases de planejamento, de implantação, de operação e, se for o caso, de desativação do empreendimento;

\section{Proposição de medidas mitigadoras:}

Explicitar as medidas que visam minimizar os impactos adversos identificados e quantificados no item anterior, devendo ser classificados quanto: 
- À sua natureza - preventiva ou corretiva (se uma área de APP, por exemplo, deverá ser isolada, preventivamente; ou recuperada, caso esteja sendo usada e, ou, degradada);

- À fase do empreendimento que deverá ser adotada - planejamento, implantação, operação, desativação e para o caso de acidentes;

- Ao fator ambiental a que se destina - físico biótico ou socioeconômico;

- Ao prazo de permanência de sua aplicação - curto, médio ou longo;

- À responsabilidade por sua implementação - empreendedor, poder público ou outros; e

- À avaliação de custos das medidas mitigadoras.

Programa de acompanhamento e monitoramento dos impactos ambientais:

Deverão ser apresentados os programas de acompanhamento da evolução dos impactos ambientais positivos e negativos causados pelo empreendimento, considerando-se as fases de planejamento, de implantação, de operação e de desativação, se for o caso, e de acidentes;

\section{Detalhamento dos fatores ambientais:}

O grau de detalhamento em cada EIA, dependerá da natureza do empreendimento, da relevância dos fatores em face de sua localização e dos critérios adotados pela equipe responsável pela elaboração do Estudo:

\section{a) Meio físico:}

1) clima e condições meteorológicas; precipitação total média; delimitação do período seco e chuvoso; entre outros;

2) qualidade do ar;

3) ruído;

4) geologia;

5) geomorfologia;

6) solos;

7) recursos hídricos;

8) hidrogeologia; e

9) qualidade das águas.

\section{b) Meio biótico:}

1) flora e vegetação; e

2) fauna.

c) Meio socioeconômico, caracterizar:

1) a dinâmica populacional;

2) uso e ocupação do solo;

3) uso da água;

4) patrimônio natural e cultural;

5) nível de vida;

6) estrutura produtiva e de serviços; e

7) organização social.

O EIA pode ser considerado como uma ferramenta de planejamento que auxilia o executor, inclusive os responsáveis por projetos de recuperação ambiental, na antecipação dos impactos das atividades das alternativas de desenvolvimento, ambas benéficas ou adversas. Fornece uma visão para selecionar a alternativa ótima na qual potencialize os efeitos benéficos e mitigue os impactos adversos ao ambiente (BISWAS e GEPING, 1987). 
Porém, para que se torne efetivamente um instrumento de auxílio à tomada de decisão, precisa estar inserido de forma articulada ao processo de planejamento, em todos os sentidos: a) horizontalmente, articulada às esferas política, tecnológica e econômica; e b) verticalmente, associada às diferentes etapas do processo de planejamento, devendo ser efetuada antes do início de um empreendimento, paralelamente à avaliação técnico-econômica (MAGRINI, 1989).

De acordo com Bitar; Fornasari Filho; Consoni (1996), a realização de EIAs no Brasil tem acumulado ao longo dos anos vários problemas relacionados à abordagem do meio físico, tais como:

a) predomínio de abordagens na caracterização do meio físico;

b) escassez de dados obtidos em levantamentos ou inspeções de campo;

c) inadequação entre a dimensão das obras propostas e as escalas das cartas do meio físico apresentadas;

d) cartas do meio físico desprovidas de conteúdos representativos da dinâmica atuante;

e) ausência de identificação de importantes impactos decorrentes de modificações impostas ao meio físico; e

f) ausência de indicadores do meio físico.

\subsubsection{Planejamento da recuperação}

Para que os objetivos sejam atingidos com sucesso, a condição ideal exige que as estratégias de recuperação sejam finalizadas antes da perturbação do solo, considerando-se, principalmente:

- As prováveis e possíveis consequências da perturbação;

- O projeto de gerenciamento de regras que facilitem a recuperação; e

- A avaliação de alternativas de práticas de recuperação, para suprir eventualidades.

Ou seja, devem ser traçadas as consequências, as metas de recuperação (inclusive a definição do uso futuro) e conhecidos os requisitos legais. Em áreas já degradadas, como áreas de cafeicultura, aquicultura e ecossistemas aquáticos (nascentes e vegetação ciliar), só resta a adequação ambiental e a realização dos procedimentos de recuperação.

\subsubsection{Administração do material}

Todos os custos devem ser analisados com a devida antecedência, visando a economia de recursos e riscos ambientais provenientes da interrupção dos procedimentos de recuperação. Devem ser detectados para cada tipo de procedimento de recuperação, que irão variar de acordo com a atividade e o estágio em que se encontram os processos de degradação. No caso da mineração, por exemplo, que é um dos casos mais complexos de recuperação, deve ser observado os seguintes procedimentos:

a) a caracterização dos estéreis, tanto para possível uso durante o processo de revegetação, como para se avaliar a qualidade da água;

b) a alcalinidade ou a acidez provenientes da camada de estéril;

c) nutrientes extraíveis;

d) as propriedades físicas e litológicas dos estéreis;

e) o plano de fechamento da mina; 
f) o isolamento de materiais tóxicos, de metais pesados e a concentração de sais, que caso seja alta, resulta em elevada condutividade elétrica do sistema;

g) a composição e a formulação do "topsoil" substituto; e análise de custos do manuseio do material.

\subsubsection{Retirada do "topsoil" ou provisão de um apropriado que o substitua}

Esse procedimento é obrigatório em áreas que serão mineradas. Quanto melhor for a qualidade do "topsoil", mais rápido será o crescimento da vegetação utilizada no processo de revegetação, evitando inclusive, a origem de processos erosivos e diminuindo os impactos ambientais. Durante esse procedimento, deve-se minimizar a área decapeada, removendo apenas o necessário. Essa atitude ajuda a reduzir os custos requeridos à recuperação. É aconselhável que possua pelo menos $25 \mathrm{~cm}$ e recebam calagem e adubação, durante a sua recolocação.

\subsubsection{Recomposição topográfica e paisagística}

Refere-se ao preparo do relevo para receber a vegetação, objetivando uma forma estável e adequada para o futuro uso do solo. A maioria das paisagens naturais é formada por bacias hidrográficas, compostas de encostas e linhas de fluxos, arranjadas de forma espacial, para que de uma forma eficaz, transportem água e sedimentos. A perturbação do solo rompe esse equilíbrio dinâmico, causando disparidades entre forças e resistências, acelerando as taxas dos processos erosivos (Figura 22).

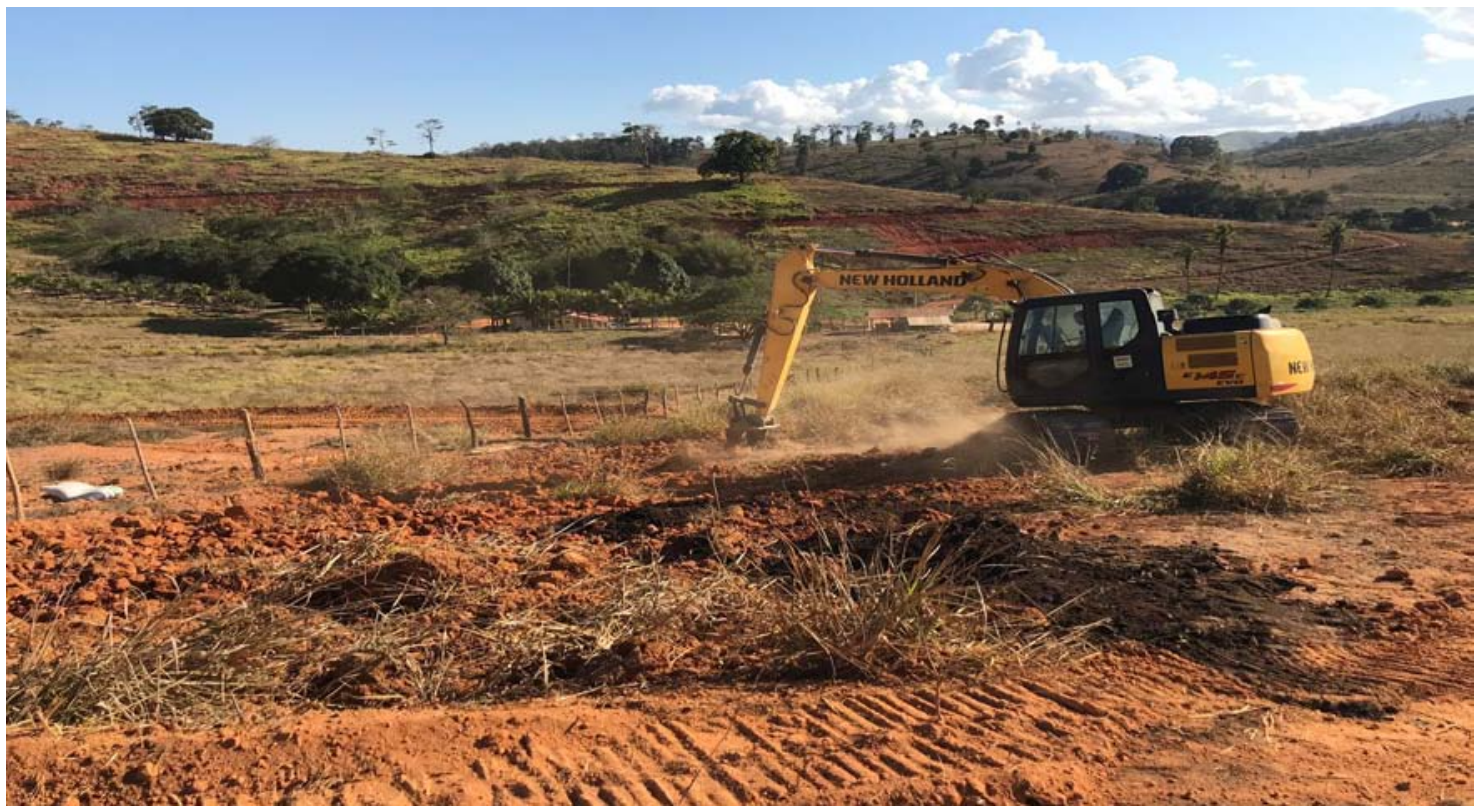

Figura 22. Retroescavadeira realizando escarificação e recomposição topográfica. Fonte: Arquivo pessoal (propriedade do Professor José Francisco Lopes).

A reconstrução topográfica deve recriar uma situação que permita um relativo equilíbrio, entre os processos e as pedopaisagens, entre forças e resistências. Devem ser observadas:

- As exigências legais;

- A declividade dos taludes (o ideal seria que o terreno ficasse plano ou com pouca declividade) de tal forma que reduzam os riscos de erosão e proporcionem a estabilidade do solo e dos taludes. 
Em terrenos com declividade superior a 20\%, devem ser construídos terraços de base larga ou estreita. Em áreas muito degradadas, como as mineradas, as bancadas (fatia horizontal que se lavra em uma mina, caracterizada por uma berma e um talude), com uma leve inclinação para dentro, ou seja, da crista do talude inferior para a base do talude superior.

Ao longo da berma da bancada, em seu sentido longitudinal, a declividade não deve ultrapassar $2 \%$, sendo necessário o seu direcionamento até atingir os canais de drenagem que conduzam as águas resultantes do escoamento superficial até a base do talude, sendo reconectadas ao sistema regional de drenagem.

Em solos argilosos e pouco erodíveis, têm sido possível remoldar a superfície de taludes com até $40 \%$ de declividade, sem a construção de bancadas, observando:

- A dinâmica das linhas de fluxo, considerando suas formas e dimensões;

- A reconstrução da bacia hidrográfica (na medida do possível, devem ser pequenas em área e suaves no relevo);

- O uso futuro previamente definido (caso seja para a manutenção da vida selvagem, construir murundus (até 1 a $2 \mathrm{~m}$ de altura) e algumas depressões pequenas, suaves e rasas, durante a obra de terraplenagem, visando a acumulação de água: tais elementos contribuem para a atração de animais;

- O tipo de equipamentos a serem empregados; e

- Os aspectos paisagísticos e estéticos, que deverão preservar as paisagens de destaque, como parques e reservas. Também, manter alguma similaridade com o relevo anterior, podendo, inclusive, melhorar e complementar a paisagem com o remanejamento do relevo e a introdução de novas plantas e espécies arbóreas.

\subsubsection{Manipulação do solo de superfície}

É realizado após a reconstrução topográfica e a recolocação do "topsoil", processo denominado preenchimento, que resulta na inversão de horizontes.

Devido ao grande número de inter-relações existentes entre as características do substrato remanescente, do solo recém-constituído e o processo de revegetação, que é a meta a ser alcançada e o principal objetivo da recuperação, é necessário que se conheça profundamente o material existente na área que será recuperada.

Geralmente, ocorre a compactação do substrato, particularmente, pelo uso intenso de máquinas pesadas durante o aplainamento da superfície, sendo necessária a escarificação ou subsolagem do substrato previamente ao plantio.

A espessura do "topsoil" deve ser definida de acordo com o volume disponível para determinada área, devendo ser regular e disposta de tal forma que cubra toda a superfície, obedecendo a conformação topográfica. A superfície recuperada deve ser modificada de forma a facilitar o gerenciamento das águas e o controle da erosão.

Deverá haver cuidados suficientes de tal forma a evitar a contaminação do lençol d'água, particularmente quando os estéreis ou rejeitos contiverem substâncias que possam comprometer a qualidade da água. Nesses casos, sempre que possível, depositar uma camada de argila sobre os componentes contaminantes de tal forma a 
isolá-los da camada fértil do solo, evitando a contaminação ambiental. A argila pode ser usada, também, sobre outros tipos de estéreis mais pobres para favorecer a revegetação.

\subsubsection{Correção do solo}

Podem ser usadas várias combinações de calcário, gesso, fertilizantes inorgânicos e materiais orgânicos (Figura 23).

A aplicação da correção depende de cinco fatores: 1) das propriedades físicas e químicas do solo; 2) do regime climático local; 3) da topografia e acessibilidade do local; 4) do tipo vegetativo a ser restabelecido e o uso do solo pós-recuperação; e 5) da conformidade com as regulações exigidas.

Deve ser feito o controle do pH do solo e aplicação de fertilizantes. Dadas essas condições iniciais e sendo adequadas com relação aos nutrientes, a produtividade em longo prazo do sistema solo-planta, dependerá de dois processos importantes: 1) acumulação de matéria orgânica e de nitrogênio; e 2) estabelecimento de um depósito de $P$ orgânico, para que possa ocorrer uma mínima absorção de $P$ pelas plantas (SOUZA, 2018).

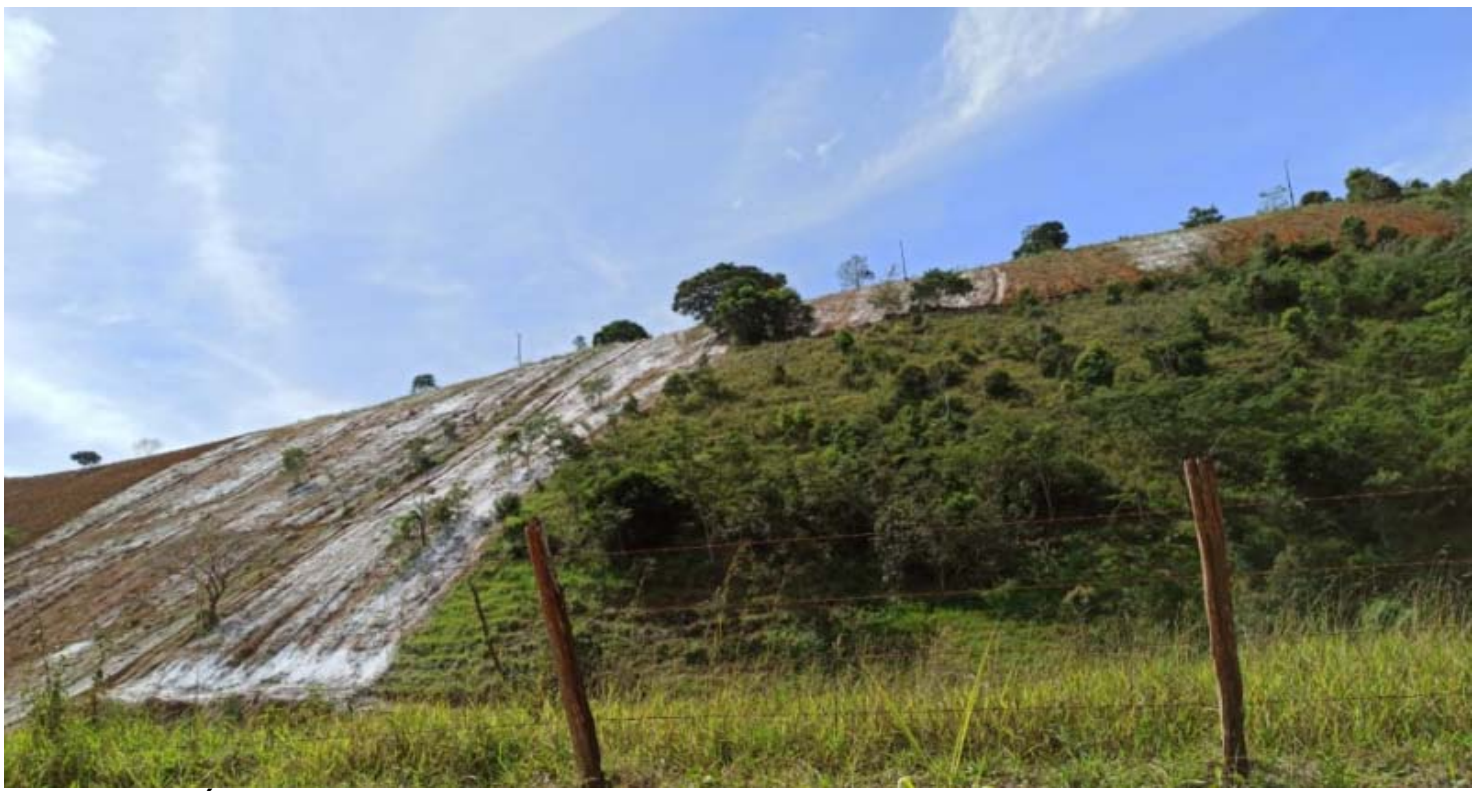

Figura 23. Área recebendo calcário para futuro plantio de lavoura de café Fonte: Arquivo pessoal (Foto de Romário Serafini).

\subsubsection{Revegetação}

É a meta principal da recuperação, resultando em benefícios secundários desejáveis, estéticos e na qualidade da água. As metas de revegetação variam do simples controle de erosão, até a complexa restauração de comunidades nativas. As abordagens e métodos empregados devem ser específicos para cada região, local e uso futuro do solo (Figuras 24 e 25). 


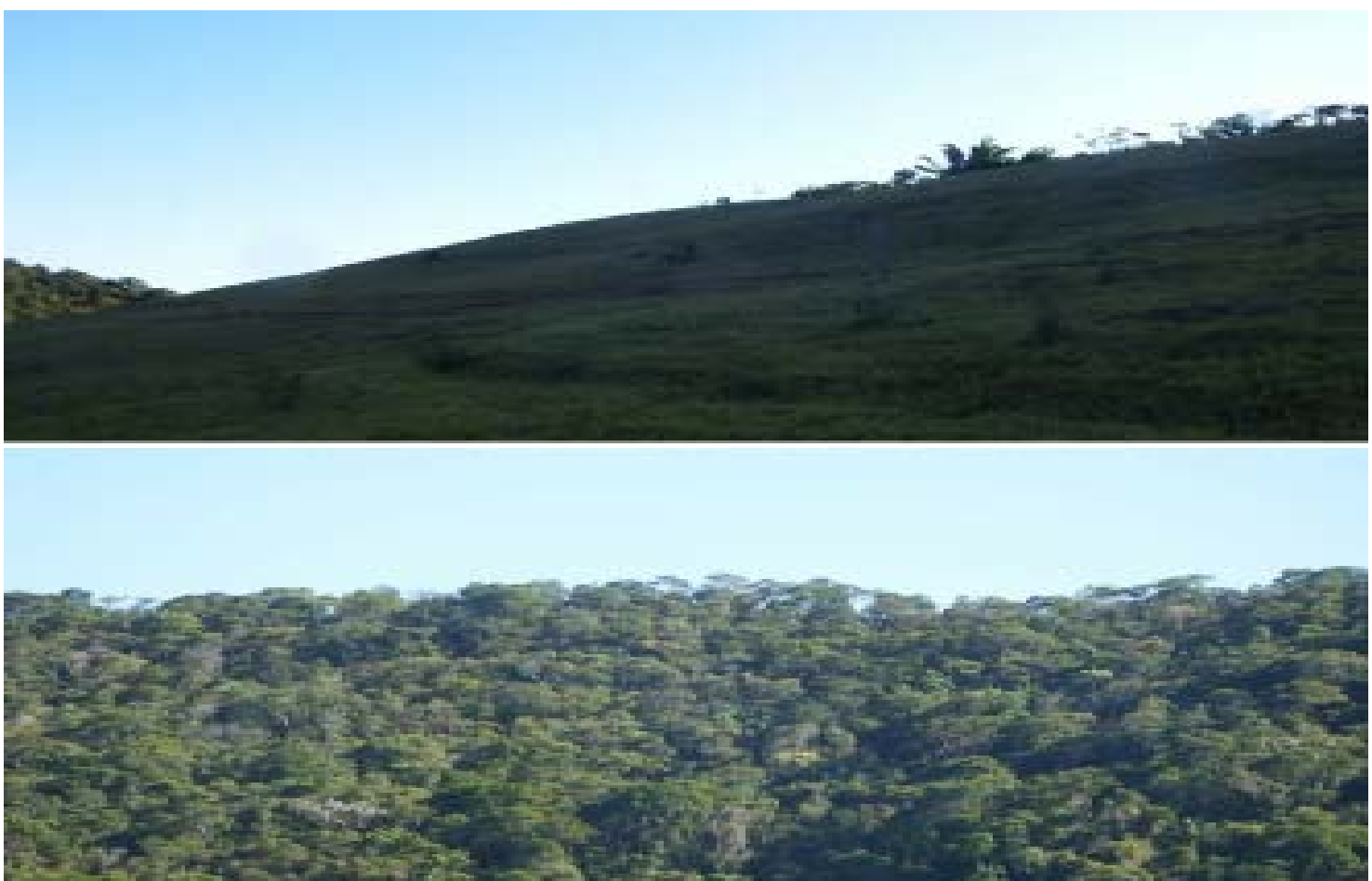

Figuras 24 e 25. Área revegetada em 2005 e 11 anos depois: IF Sudeste de Minas campus Rio Pomba.

São os seguintes princípios básicos para o sucesso da revegetação (SOUZA, 2004; 2018):

1) seleção de materiais e plantas - deve ser feito um levantamento florístico ou fitossociológico e, as espécies nativas adaptadas devem ser as preferidas, devendo lembrar que solos com distúrbios são muito diferentes de solos em condições naturais. Dessa forma, espécies exóticas podem ser mais bem sucedidas que espécies nativas, particularmente quando as condições do solo resultam de situação de distúrbio. $O$ banco de semente de espécies nativas, contidas no "topsoil" ou na camada de "litter", apresenta ganhos diretos e são utilizados para prover o material localmente adaptado para as plantas;

2) preparação das sementeiras;

3) observar as técnicas de semeadura de acordo com as espécies; e

4) utilização de cobertura morta ("mulching").

De acordo com GRIFFITH (2002), apesar dos avanços das pesquisas nessa área, em função da diversidade florística e das variações edafoclimáticas, ainda falta muito para aprender sobre a dinâmica ecológica.

\subsubsection{Irrigação (caso necessário)}

Em locais que apresentam condições climáticas irregulares, deve ser incluído o procedimento de irrigação durante o estabelecimento das mudas. Entretanto, considerando a dificuldade de se realizar tal prática, recomenda-se o uso de "hidrogel" (Gel Retentor de Água ou Solo Gel) - é um polímero com alta capacidade de retenção de água, podendo reter centenas de vezes seu próprio peso. Age como uma reserva de água para as plantas, tornando-a disponível de acordo com a necessidade, reduzindo o stress hídrico, os efeitos da estiagem e a mortalidade de plantas. 
Uma opção é utilizar composto e, ou, adubo orgânico nas covas para aumentar a retenção de água na região das raízes das mudas recém-plantadas. Também, uso de mulching preto/branco, com dupla função: reduzir a competição com plantas espontâneas e retenção da umidade - melhor ainda quando é coberto com vegetação seca das proximidades (Figuras 26 e 27).

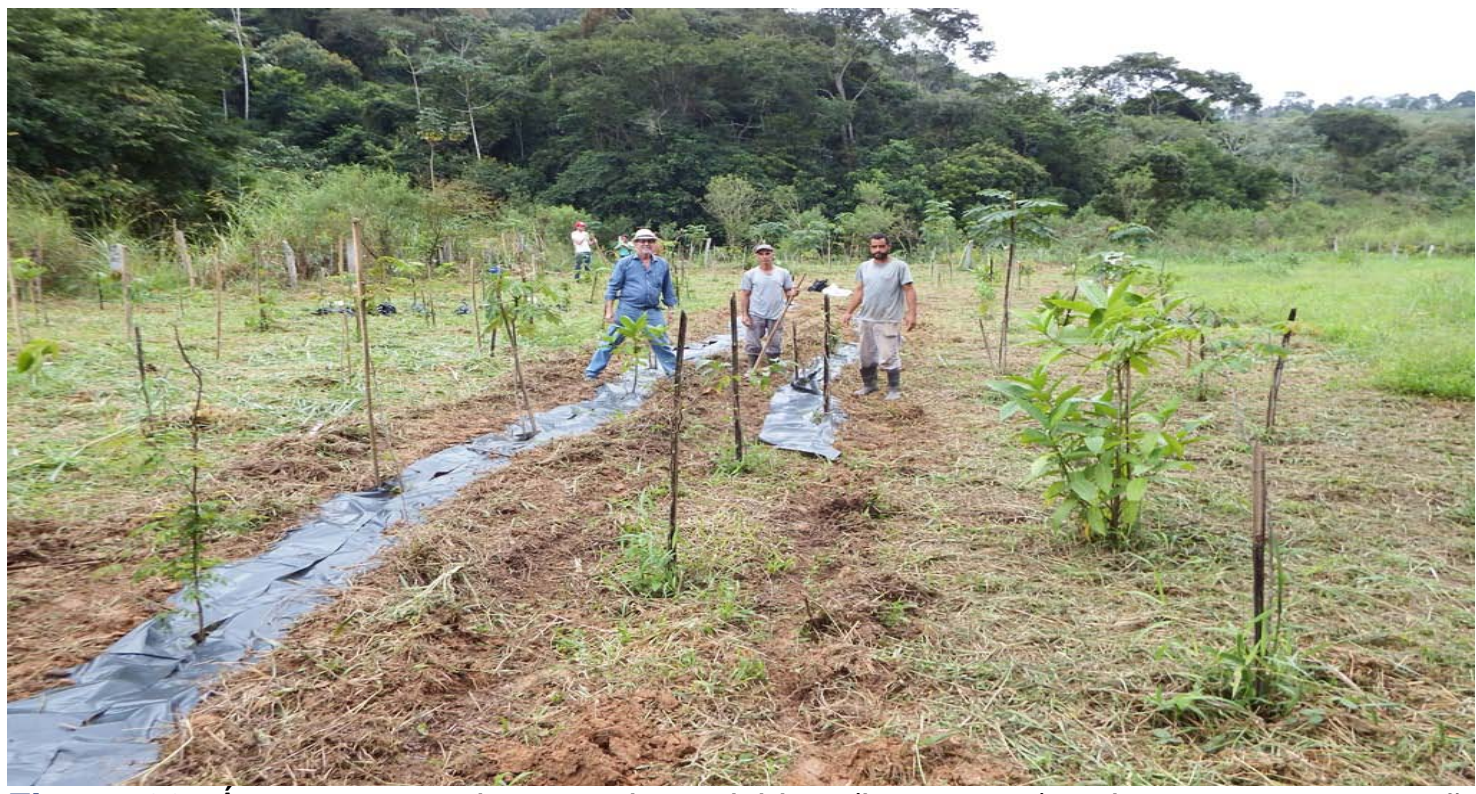

Figura 26. Área revegetada: uso de mulching (lona preta) coberta com vegetação seca.

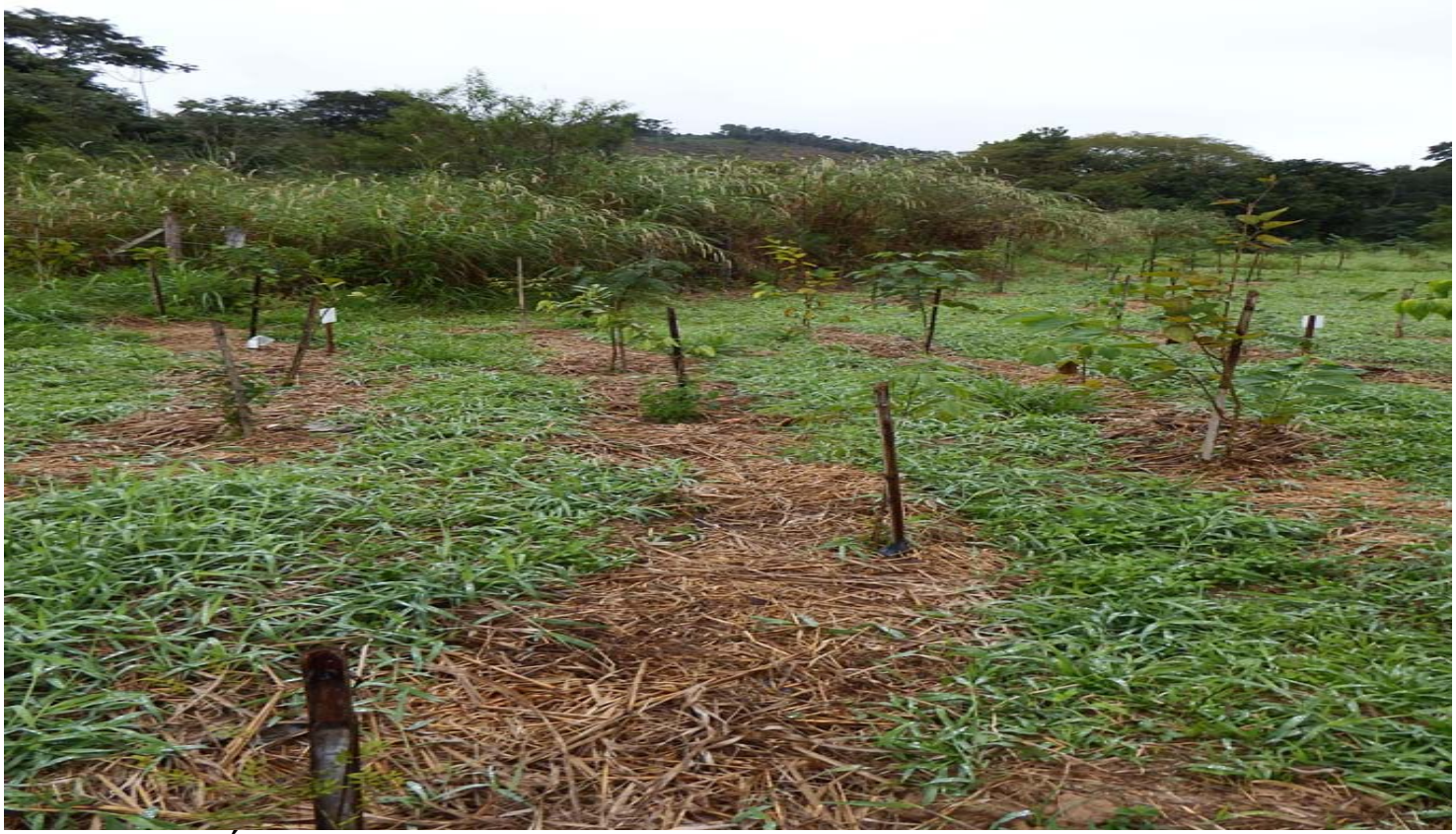

Figura 27. Área revegetada com o uso de mulching (lona preta) coberta com vegetação seca: quinze dias após o plantio.

\subsubsection{Monitoramento e manutenção}

O gerenciamento do solo, depois dos procedimentos de recuperação, inclui monitoramento local e manutenção, quando serão avaliados os recém-construídos sistemas ambientais e sua integração com a circunvizinhança. Devem ser usados 
indicadores e informações do banco de dados. Merecem atenção especial (SOUZA, 2004; 2018):

1) a quantidade, a qualidade e o controle da água de superfície e de subsuperfície;

2) a quantidade e a qualidade da cobertura vegetal, ou seja, o volume de biomassa e a diversidade, sendo necessário em alguns casos refazer a semeadura ou o plantio;

3) as taxas de processos geomorfológicos, como movimento de massas e erosão. Caso necessário, realizar a manutenção dos terraços em camalhões, taludes de bancadas e das obras de drenagem;

4) observar sintomas de deficiência nutricional (realizar adubação de cobertura) ou toxidez pelo excesso de algum elemento;

5) diagnosticar e realizar o controle de pragas - formigas, prioritária e obrigatoriamente, devem ser controladas; e doenças;

6) não permitir pastoreio nos dois primeiros anos para favorecer a sementação para germinação natural no ano seguinte;

7) realizar o coroamento das espécies arbóreas;

8) realizar incorporação de vegetação morta ou outras matérias orgânicas para promover a melhoria na estrutura do solo; e

9) manejar adequadamente a predominância das espécies desejadas.

Embora a maior parte das pesquisas e resultados seja baseada em experiências com solos de mineração de superfície, os princípios são aplicados para outros tipos de perturbações de solos, tais como pedreiras, lavra de rochas ornamentais, mineração de metal, estrada, industrial e construção urbana/residencial. Áreas agropecuárias e florestais degradadas pelo uso intensivo de agroquímicos, também podem adotar procedimentos semelhantes.

Por outro lado, áreas que serão destinadas à Reserva Legal (RL), APP (áreas de preservação permanente), tais como nascentes e vegetação ciliar dos ecossistemas aquáticos, implantação de SAFs (Sistemas agroflorestais) e sistemas ILPF (integração lavoura-pecuária-floresta), podem seguir apenas parte dessas etapas, desde que as condições locais não possuam graves riscos ambientais e, ou, elevados níveis de contaminação/poluição.

\section{Considerações finais}

Os procedimentos de recuperação ambiental devem ter por objetivo auxiliar o desenvolvimento sustentável. Para atingi-lo, a busca deve ser no sentido de propostas alternativas sistêmicas e sinergéticas, tendo como modelo os próprios ecossistemas naturais e com o envolvimento de toda a sociedade.

Infelizmente, existem gargalos que têm dificultado os procedimentos de recuperação ambiental, tais como: a) a indefinição de políticas públicas; e b) a falta de ações concretas por parte 1) das organizações de pesquisa e ensino, exigindo novas diretrizes com profundas transformações estruturais; e 2) dos órgãos legisladores, regulamentadores, certificadores e fiscalizadores, exigindo do setor produtivo o cumprimento da legislação. Este último, demonstrando excessiva cautela em situações onde a punição deveria ser mais imediata e rigorosa.

A pesquisa evoluiu significativamente em todo o mundo. Porém, no Brasil, faltam recursos, parcerias com a indústria e um maior intercâmbio entre as diversas instituições de pesquisa. Essa tomada de decisão reduziria os custos e aceleraria os resultados dos procedimentos de recuperação ambiental, criando situações de maior 
dinamismo e cooperação, posto o caráter multidisciplinar que essa ciência possui e exige.

Nos procedimentos de recuperação propriamente ditos, observados todos os requisitos ambientais, sociais, legais e técnicos, o planejamento cuidadoso, a manipulação dos materiais, a reconstrução topográfica e a seleção das espécies para a revegetação, representam a chave para o sucesso. Raramente é possível projetar tais estratégias, para que sejam efetivas e duradouras, sem um profundo conhecimento de trabalhos relativos à perturbação de solo/água e práticas responsáveis pelos impactos ambientais que exigem recuperação.

Em função dessa realidade, é necessário para gerentes de recuperação, interagir e entender as perspectivas diversas de engenheiros, geólogos, cientistas de solo, hidrologistas, biólogos e outros profissionais das disciplinas relacionadas, como aquelas anteriormente citadas. Também, estratégias de recuperação devem ser financeiramente viáveis e claramente comunicadas aos proprietários da área e ao órgão responsável pelo controle e fiscalização.

A recuperação de locais com distúrbios envolve uma variedade de práticas de manejo de curto e longo prazo, normalmente projetadas antes da perturbação, para minimizar os impactos adversos e maximizar o potencial produtivo futuro do local. Porém, é importante perceber, que alguns efeitos de curto prazo, como aumento do escoamento superficial, produção de sedimentos e deslocamento da vida selvagem, são inevitáveis em atividades perturbadoras de solo.

Assim, embora o enfoque das metas de recuperação ou reconstrução da pedopaisagem seja de longo prazo, todo impacto hidrológico, estratégias de revegetação e recuperação após o uso do solo, deve-se estabelecer um programa ativo de mitigação dos impactos temporários, devendo ser incluído em planos contingenciais de operações diárias.

Finalmente, o local recuperado deverá fundir-se amplamente com a paisagem da qual será uma parte funcional. A paisagem circundante provê áreas de referência para pesquisa comparativa. Frequentemente, é possível utilizar o processo de recuperação para produzir pedopaisagens mais produtivas àquelas originalmente ocupadas no local. Isto é nitidamente possível, quando o pré-distúrbio da paisagem foi previamente degradada por erosão de solo, movimentos de massa ou antigo local de pastagem ou mineração.

Posteriormente, para que o sucesso e o equilíbrio da área recuperada sejam alcançados e conservados, dependerá, em grande parte, da maneira como o solo será utilizado e manejado. Práticas conservacionistas e manejo terão grande influência sobre processos erosivos que influenciarão na produtividade dessas áreas.

Por esse motivo, para uma exploração racional, a área recuperada deverá ser utilizada de acordo com a sua capacidade de uso. Na ocorrência de excessos, que ultrapassem o limite de sua capacidade de suporte, haverá riscos de deterioração. Isso é importante no caso de áreas recuperadas, particularmente com referência a uma questão que nem sempre tem sido abordada: o custo do "progresso".

Observando-se a História, particularmente a mais recente, aprende-se que apesar de ter havido crescimento econômico e um considerável avanço da ciência, em função das diversas condições de desequilíbrio que interferiram significativamente sobre as condições ambientais, na maioria das vezes situações criadas pelo próprio progresso, não houve uma melhoria equitativa na qualidade de vida que o justifique. 
Ao mesmo tempo, diante do contínuo crescimento populacional, exigindo um aumento proporcional na demanda por alimentos e na geração de empregos e renda, é necessário que sejam tomadas medidas imediatas para alteração dos modelos de produção e de desenvolvimento. Mesmo tendo havido significativos avanços em recuperação ambiental, é necessário poupar os recursos naturais imprescindíveis ao desenvolvimento socioeconômico, visando uma concreta melhoria na qualidade de vida atual e que crie condições de sustentabilidade para as futuras gerações. Esse é o grande desafio para que ocorra uma nova ordem ambiental, em todo o mundo: mais justa, saudável e equilibrada.

São fundamentais a adoção de sistemas de gestão ambiental pelas empresas e a educação ambiental da população. Deverão ocorrer com a incorporação de novos valores onde a ética e a moral sejam componentes integrantes desse novo modelo. Dessa forma, poderá evitar novos casos de degradação e manterem-se as áreas recuperadas. Para isso, faz-se necessário o acesso à informação e a criação de uma visão compartilhada com a sociedade. Somente dessa forma, os procedimentos de recuperação ambiental serão efetivamente duradouros, tornando-se possível 0 desenvolvimento sustentável.

Atualmente, a exploração agropecuária, florestal e industrial racional, é o desafio do século XXI. Para tanto, é necessário que sejam revistos os conceitos em termos de manejo e de utilização de práticas conservacionistas. Deve-se adotar uma educação ambiental crítica voltada para a necessária transformação da sociedade, para que esse cenário possa ser revertido na direção da sustentabilidade, baseada em novas condições que reordenarão os novos modelos de produção.

Nos Capítulos 2 e 3, serão apresentados dois Estudos de Caso que mostrarão propostas de atividades que sugerem que o crescimento econômico esteja associado ao desenvolvimento sustentável: a aquicultura e a cafeicultura.

\section{Referencias}

ANDREAZZI, M. A. R.; MILWARD-DE-ANDRADE, R. Impactos das grandes barragens na saúde da população - uma proposta de abordagem metodológica para a Amazônia. In: SIMPÓSIO INTERNACIONAL DE ESTUDOS AMBIENTAIS DE FLORESTAS TROPICAIS ÚMIDAS, 1990, Manaus. Anais... Rio de Janeiro: Biosfera, 1992. p.370383.

BARROS, N. F.; NOVAIS, R. F. Algumas relações solo-espécie de eucalipto. In: BARROS, N. F.; NOVAIS, R. F. (Eds.) Relação solo-eucalipto. Viçosa: Editora Folha de Viçosa, 1990. p.1-24.

BERNARDES, J. A.; FERREIRA, F. P. M. Sociedade e Natureza. In: CUNHA, S. P.; GUERRA, A. J. T. (Org.) A questão ambiental: diferentes abordagens. Rio de Janeiro: Bertrand Brasil, 2003. p.17-42.

BERTONI, J.; LOMBARDI NETO, F. Conservação do solo. São Paulo: Ícone, 1990. $355 p$.

BISWAS, A. K.; GEPING, Q. Guidelines for environmental impact assessment in developing countries. In: BISWAS, A. K; GEPING, Q. (Eds.) Environmental impact assessment for development countries. Londres: Tycooly International, 1987. p.191-232. 
BITAR, O. Y.; FORNASARI FILHO, N.; CONSONI, A. J. A abordagem do meio físico em EIA através do estudo de processos: um método recomendado para empreendimentos em ambientes tropicais. Avaliação de Impactos Ambientais, v.1, n.2, p.35-45, 1996.

BLUM, W. E. H. Basic concepts: degradation, resilience and rehabilitation. In: LAL, R; BLUM, W. H.; VALENTINE, C.; STEWART, B. A. (Eds.). Methods for assessment of soil degradation. New York: CRC Press, 1998. p.1-16.

CARPANEZZI, A. A. et al. Espécies pioneiras para recuperação de áreas degradadas: observação em laboratórios naturais. In: CONGRESSO FLORESTAL BRASILEIRO, 6., 1990. Campos do Jordão. Anais... São Paulo: SBS/SBEF, 1990. p.216-221.

CASTELLS, M. O poder da identidade. São Paulo: Paz e Terra, v. 2, 1999. 141p.

CASTRO FILHO, C.; MUZILLI, O. Importância do conhecimento de solos e nutrição de plantas para o Engenheiro Florestal. Folha Florestal, n. 101, p.21-23, 2002.

COELHO, M. C. N. Impactos ambientais em áreas urbanas - teorias, conceitos e métodos de pesquisa. In: GUERRA, A. J. T.; CUNHA, S. B. C. (Org.) Impactos ambientais urbanos no Brasil. Rio de Janeiro: Bertrand Brasil, 2001. p.19-45.

CUNHA, S. B.; GUERRA, A. J. T. Avaliação e perícia ambiental. Rio de Janeiro: Bertrand Brasil, 1999. 266p.

CUNHA, S. P. Canais fluviais e a questão ambiental. In: CUNHA, S. P.; GUERRA, A. J. T. (Org.) A questão ambiental: diferentes abordagens. Rio de Janeiro: Bertrand Brasil, 2003. p.219-238.

CURTIA, W.; DYER, K.; WILLIAMS, G. A Manual for training reclamation inspectors in the fundamentals of hydrology. , Washington, D.C.: U. S. Dept. of Agriculture, Forest Serri, Northeastern Forest Experiment. Sta., Berea, Ky. U.S. Government Printing Office, 1994. 345p.

DIAS, L. E. Caracterização de área degradada e fontes de degradação ambiental. Notas de aula da disciplina Recuperação de Áreas Degradadas. Departamento de Solos. UFV, Viçosa, MG, 2003a. p.11-33.

DIAS, L. E. Recuperação de áreas degradadas. In: ENCONTRO DE PRESERVAÇÃO DE MANANCIAIS DA ZONA DA MATA MINEIRA, 3., 2003, Viçosa, MG. Anais... Viçosa: ABES-MG/DEA UFV, 2003b. p.225-268.

DIAS, L. E.; GRIFFITH, J. J. Conceituação e caracterização de áreas degradadas. In: DIAS, L. E.; MELLO, J. W. V. (Eds.) Recuperação de Áreas Degradadas. Viçosa: UFV, Departamento de solos; Sociedade Brasileira de Recuperação de Áreas Degradadas, 1998. p.1-8.

DORAN, J. W.; PARKIN, T. B. Defining and assessing soil quality. In: DORAN, J. B.; COLEMAN, D. C.; BEZDICEK, D. F.; STEWART, B. A. (Eds.) Defining soil quality for a sustainable environment. Soil Science Society of America. Madison: SSSA. 1994. 244p. (Special publication number 5).

FOSTER, G. R. Modeling the erosion process. In: HAAN, C. T.; JOHNSON, H. P.; BRAKENSIEK, D. L. (Eds.). Hydrologic Modeling of Small Watersheds. St. Joseph, MI: American Society of Agricultural Engineers, 1982. p.297-382. 
GRIFFITH, J. J. Informações pessoais. Professor do Departamento de Engenharia Florestal. Viçosa: UFV, out. 2003.

GRIFFITH, J. J. Informações pessoais. Professor do Departamento de Engenharia Florestal. Viçosa: UFV, fev. 2004.

GRIFFITH, J. J. Recuperação ambiental: uma abordagem sistêmica. Viçosa: UFV Departamento de Engenharia Florestal. Universidade Federal de Viçosa, 2002. (Apostila da disciplina ENF391 - Recuperação de Áreas Degradadas).

GRIFFITH, J. J. Recuperar áreas degradadas é zelar pelas futuras gerações. Informe agropecuário, v.22, n.210, p.1-2, 2001.

GRIFFITH, J. J.; DIAS, L. E.; MARCO JÚNIOR, P. A recuperação ambiental. Rev. Ação Ambiental, v.2, n. 10., p.8-11, 2000.

HARRIS, J. A.; BIRCH, P.; PALMER, J. P. Land restoration and reclamation: principles and practice. Addison Wesley: Longman, Essex, 1996. 230p.

IBAMA - INSTITUTO BRASILEIRO DO MEIO AMBIENTE E DOS RECURSOS NATURAIS RENOVÁVEIS. Manual de recuperação de áreas degradadas pela mineração: técnicas de revegetação. Brasília: IBAMA, 1990. 96p.

IEMA - Instituto Estadual de Meio Ambiente e Recursos Hídricos. EIA - Estudo de Impacto Ambiental do Projeto de Implantação da Central de Tratamento de Resíduos - Terramar. Disponível em: <https://iema.es.gov.br/Media/iema/CQAI/EIA/ 2008/Terra mar/5\%20-\%20Diagnostico\%20Ambiental\%20.pdf>. Acesso em: 25 out. 2020. 330 p.

KOBIYAMA, M.; MINELLA, J. P. G.; FABRIS, R. Áreas degradadas e sua recuperação. Informe Agropecuário, v.22, n.210, p.10-17, 2001.

KOBIYAMA, M.; USHIWATA, C. T.; BARCIK, C. Recuperação de áreas degradadas: conceito, um exemplo e uma sugestão. Bio., n.6, p.95-102, 1993.

LAMPRECHT, H. Silvicultura nos trópicos: ecossistemas florestais e respectivas espécies arbóreas - possibilidades e métodos de aproveitamento sustentado. Alemanha: Instituto de Silvicultura da Universidade de Göttingen, 1990. 343p.

LESCURE, J. P.; PINTON, F.; EMPERAIRE, L. Povos e produtos da floresta na Amazônia Central: o enfoque multidisciplinar do extrativismo. In: VIEIRA, P. F.; WEBER, J. (Org.) Gestão de recursos naturais e renováveis: novos desafios para a pesquisa ambiental. São Paulo: Cortez, 1997. p.433-468.

LIMA, G. F. C. O debate da sustentabilidade na sociedade insustentável. Rev. Política \& Trabalho, PPGS/UFPB, n.13, p.4, 1997.

MACHADO, P. A. L. Regulamentação do estudo de impacto ambiental. Rev. Inf. Leg., V.24, n.93, p.329-338, 1987.

MAGRINI, A. Avaliação de impactos ambientais e a região amazônica. In: Impactos ambientais de investimentos na Amazônia: problemática e elementos de avaliação. Manaus: Projeto BRA/87/021 - SUDAM/PNUD/BASA/SUFRAMA e Projeto BRA/87/040 - ELETRONORTE/PNUD, 1989. 53p (mimeografado). 
MARTINS, S. V. Recuperação de áreas degradadas: ações em áreas de preservação permanente, voçorocas, taludes rodoviários e de mineração. Viçosa: Aprenda Fácil, 2009. 270 p.

MINISTÉRIO DO MEIO AMBIENTE. Instrução Normativa $\mathbf{n}^{\mathbf{0}} \mathbf{5}$, de 8 de setembro de 2009. Disponível em: <https://idaf.es.gov.br/Media/idaf/Documentos /Legisla\%C3\%A7\%C3\%A3o/DRNRE/IN\%20MMA\%20n\%C2\%BA\%20003,\%20de\%200 8\%20de\%20setembro\%20de\%202009.pdf>. Acesso em: 23 maio 2019.

MOREIRA, I. V. D. Avaliação de impacto ambiental. Rio de Janeiro: FEEMA, 1985. $34 p$.

NARDELLI, A. M. B.; NASCIMENTO, A. R. O planejamento na recuperação ambiental. Rev. Ação Ambiental, n.10, p.13-15, 2000.

ODUM, E. P. Ecologia. Rio de Janeiro: Guanabara, 1988. 434p.

OLSON, K. R.; LAL, R.; NORTON, L. D. Evaluation of methods to study soil erosionproductivity relationships. J. Soil Water Conservation, v.49, n.6, p.586-590, 1994. Disponível em: <https://www.jswconline.org/content/49/6/586>. Acesso em: 05 Jan. 2021.

PRIMAVESI, A. Manejo ecológico do solo: a agricultura em regiões tropicais. São Paulo: Nobel, 1987. 549p.

REINERT, D. J. Recuperação de solos em sistemas agropastoris. In: DIAS, L. E.; MELLO, J. W. V. (Eds.). Recuperação de Áreas Degradadas. Viçosa: UFV, Departamento de solos; Sociedade Brasileira de Recuperação de Áreas Degradadas, 1998. p.163-176.

RESENDE, M. et al. Pedologia: base para distinção de ambientes. Viçosa: NEPUT. 2002. 338p.

SÁNCHEZ, L. E. Desengenharia: o passivo ambiental na desativação de empreendimentos industriais. São Paulo: USP, 2001. 256p.

SCHAEFER, C. E. et al. Elementos da paisagem e a gestão da qualidade ambiental. Informe Agropecuário, v.21, n.202, p.20-44, 2000.

SCHLEV, S.; LAUR, J. Inovações em gerenciamento. Wendell, MA, USA: Pegasus, 1998. 29p.

SILVA, E. Análise e avaliação de impactos ambientais. Viçosa, MG: DEF/UFV, 1998. 56 p. (Apostila de ENF 685 - Avaliação de Impactos Ambientais).

SILVA, E. Avaliação de impactos ambientais no Brasil. Viçosa, MG: UFV, 1994b. 31p.

SILVA, E. Avaliação qualitativa de impactos ambientais do reflorestamento no Brasil. 1994a, 309f. Tese (Doutorado em Ciência Florestal) - Universidade Federal de Viçosa, Viçosa.

SILVA, E. Tópicos de manejo de fauna silvestre. Viçosa, MG: Imprensa Universitária, 1993. 26p. (Apostila, n. 319). 
SOUZA, M. N. Degradação antrópica e procedimentos de recuperação ambiental. Novas Edições Acadêmicas/SIA OmniScriptum Publishing: Brivibas gatve 197, LV1039, Riga, Letônia, União Europeia, 2018. 364p.

SOUZA, M. N. Degradação e Recuperação Ambiental e Desenvolvimento Sustentável. Viçosa, MG: UFV, 2004. 371p. Dissertação (Mestrado em Ciência Florestal) - Universidade Federal de Viçosa, 2004.

SOUZA, M. N. Mudanças no uso do solo e da água e a gestão dos recursos naturais. Frankfurt, Alemanha: Novas Edições Acadêmicas, 2015, v.5000. 376 p.

TAUK, S. M. T.; GOBBI, N.; FOWLER, H. G. Análise ambiental: uma visão multidisciplinar. São Paulo: UNESP,1995. 258p.

TAVARES, S. R. L. et al. Curso de Recuperação de Áreas Degradadas: a visão da Ciência do Solo no contexto do diagnóstico, manejo, indicadores de monitoramento e estratégias de recuperação. Rio de Janeiro: Embrapa Solos, 2008. 228 p.

TOY, T. J.; DANIELS, W. L. Reclamation of disturbed lands. In: MAYER, R.A. (Ed.). Encyclopedia of environmental analysis and remediation. New York: John Wiley, 1998. p.4078-4101.

TOY, T. J.; FOSTER, G. R.; RENARD, K. G. Soil erosion: processes, prediction, measurement, and control. New York: John Wiley, 2002. 338p.

VIEIRA, L. S. Manual da ciência do solo. São Paulo: Agronômica Ceres, 1975. 464p.

VIEIRA, L. S.; SANTOS, P. C. T. C.; VIEIRA, M. N. S. Solos: propriedade, classificação e manejo. Brasília: MEC/ABEAS, 1988. 154p. (Programa Agricultura nos Trópicos, v. 2)

\section{Autor}

Maurício Novaes Souza*

Professor Dr. do Instituto Federal do Espírito Santo - Campus de Alegre, Caixa Postal 47, CEP: 29500-000, Alegre-ES.

* Autor de correspondência: mauricios.novaes@ifes.edu.br 